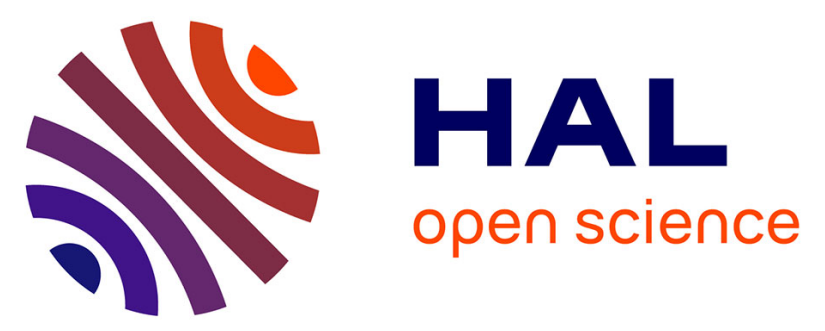

\title{
Dendro-anthracological tools applied to Scots type pine forests exploitation as fuel during the Mesolithic-Neolithic transition in the southern central pre-Pyrenees (Spain)
}

Marta Alcolea, Alexa Dufraisse, María Royo, Carlos Mazo, Martin de Luis, Luis A. Longares, Pilar Utrilla, Ramón Fábregas

\section{To cite this version:}

Marta Alcolea, Alexa Dufraisse, María Royo, Carlos Mazo, Martin de Luis, et al.. Dendroanthracological tools applied to Scots type pine forests exploitation as fuel during the MesolithicNeolithic transition in the southern central pre-Pyrenees (Spain). Quaternary International, 2020, 10.1016/j.quaint.2020.10.029 . mnhn-03008152

\section{HAL Id: mnhn-03008152}

\section{https://hal-mnhn.archives-ouvertes.fr/mnhn-03008152}

Submitted on 16 Nov 2020

HAL is a multi-disciplinary open access archive for the deposit and dissemination of scientific research documents, whether they are published or not. The documents may come from teaching and research institutions in France or abroad, or from public or private research centers.
L'archive ouverte pluridisciplinaire HAL, est destinée au dépôt et à la diffusion de documents scientifiques de niveau recherche, publiés ou non, émanant des établissements d'enseignement et de recherche français ou étrangers, des laboratoires publics ou privés. 


\section{Journal Pre-proof}

Dendro-anthracological tools applied to Scots type pine forests exploitation as fuel during the Mesolithic-Neolithic transition in the southern central pre-Pyrenees (Spain)

Marta Alcolea, Alexa Dufraisse, María Royo, Carlos Mazo, Martín de Luis, Luis A. Longares, Pilar Utrilla, Ramón Fábregas

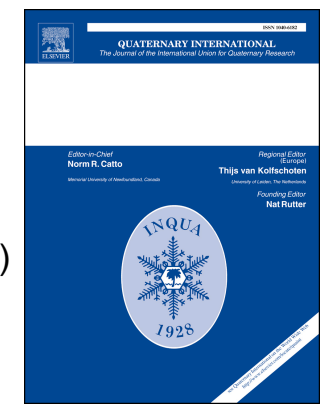

PII: S1040-6182(20)30655-8

DOI: https://doi.org/10.1016/j.quaint.2020.10.029

Reference: JQI 8574

To appear in: Quaternary International

Received Date: 7 July 2020

Revised Date: 11 October 2020

Accepted Date: 12 October 2020

Please cite this article as: Alcolea, M., Dufraisse, A., Royo, Marí., Mazo, C., de Luis, Martí., Longares, L.A., Utrilla, P., Fábregas, Ramó., Dendro-anthracological tools applied to Scots type pine forests exploitation as fuel during the Mesolithic-Neolithic transition in the southern central pre-Pyrenees (Spain), Quaternary International (2020), doi: https://doi.org/10.1016/j.quaint.2020.10.029.

This is a PDF file of an article that has undergone enhancements after acceptance, such as the addition of a cover page and metadata, and formatting for readability, but it is not yet the definitive version of record. This version will undergo additional copyediting, typesetting and review before it is published in its final form, but we are providing this version to give early visibility of the article. Please note that, during the production process, errors may be discovered which could affect the content, and all legal disclaimers that apply to the journal pertain.

(C) 2020 Published by Elsevier Ltd. 
1 DENDRO-ANTHRACOLOGICAL TOOLS APPLIED TO SCOTS TYPE PINE 2 FORESTS EXPLOITATION AS FUEL DURING THE MESOLITHIC3 NEOLITHIC TRANSITION IN THE SOUTHERN CENTRAL PRE-PYRENEES 4 (SPAIN).

5 Marta Alcolea $^{\text {a,b,c }}$, Alexa Dufraisse ${ }^{\text {b }}$, María Royo ${ }^{\text {, }}$, Carlos Mazo ${ }^{\text {e }}$, Martín de Luis ${ }^{\text {d, }}$ 6 Luis A. Longares ${ }^{d}$, Pilar Utrilla ${ }^{\mathrm{e}}$, Ramón Fábregas ${ }^{\mathrm{a}}$

$7{ }^{a}$ GEPN-AAT Research Group, Universidade de Santiago de Compostela, Praza da 8 Universidade 1, 15782, Santiago de Compostela, Spain.

9 b CNRS/MNHN, UMR 7209 Archéozoologie, Archéobotanique: Sociétés, Pratiques et 10 Environnements, Sorbonne Université, CP 56, 55 rue Buffon, 75005 Paris, France.

${ }^{\mathbf{c}}$ ISEM, CNRS, IRD, EPHE, Université de Montpellier CC 065, Place Eugène Bataillon 34095 Cedex 5 Montpellier, France.

d Departamento de Geografía. Universidad de Zaragoza, IUCA, C/ Pedro Cerbuna 12, 50009, Zaragoza, Spain.

e Departamento de Ciencias de la Antigüedad. Universidad de Zaragoza, IUCA, C/ Pedro Cerbuna 12, 50009, Zaragoza, Spain.

Corresponding author: Marta Alcolea (martaalcoleagracia@gmail.com)

Keywords: Pinus sylvestris tp., Early-Middle Holocene, firewood procurement, dendro-anthracology, anthraco-typology, charcoal analyses, referential datasets, NE Iberia.

\section{Abstract}

This work focuses on the reconstruction of fuelwood procurement during the Mesolithic-Neolithic transition in the southern central Pre-Pyrenees (Spain). The study combines wood charcoal identification with the application of dendro-anthracological approaches in the archaeological sequence of Esplugón (9.4-6.8 kyr cal BP) (Sabiñanigo, Huesca). Scots type pine (Pinus sylvestris tp.) reaches in this record around $90 \%$ of exploited firewood in line with its abundance in the inner Iberia mountainous areas during the onset of the Holocene. The classification of pine wood fragments in anthraco-groups is based on the combination of different dendroanthracological tools: i) pith location tool and wood diameter estimation based on the trigonomethric method tool (ADmodel), ii) the study of growth rate based on the annual tree-ring width measurements, and iii) a modern dendrological dataset. There are hardly any differences observed in firewood procurement between the last huntergatherers and the first farmers in the long sequences from rock-shelters with recurrent human occupations. First results from this site point to the exploitation of whole trees but a high use of small pine branches probably from the gathering of branch shedding. 
39

40

41

42

This work constitutes a holistic approach to Early-Middle Holocene archaeological wood charcoal assemblages from the southern central Pre-Pyrenees (Spain). Some of these assemblages are characterized by a very homogeneous composition, in which Scots type pine wood (Pinus sylvestris tp.) always reaches very high values, $>70 \%$, despite the taxonomic diversity of the anthracological samples. Scots type pines (Pinus sylvestris tp.) have played an important role in Mediterranean vegetation since the Pleistocene which is reflected in their ubiquity presence in several wood charcoal assemblages of southern Europe (Alcolea, 2015; Alcolea et al., 2017a; 2017b; Allué et al., 2012, 2017a; 2017b; 2018; Allué and Mas, 2020; Aura et al., 2005; Badal et al., 2012a, 2012b; Badal and Martínez-Varea, 2018; Carrión et al., 2008; 2019; Mazo and Alcolea, 2019; Montes et al., 2016; Rubiales et al., 2010; Théry-Parisot, 2001; 2002; Théry-Parisot and Thiébault, 2005; Théry-Parisot et al., 2016; 2018; Vidal-Matutano, 2017; Vidal-Matutano et al., 2015, 2017, 2018).

Pinus sylvestris L. forests show a wider world distribution area nowadays although in the Iberian Peninsula they are now restricted to the highest elevations in mountain areas (Costa et al., 2001). They are accompanied by Pinus nigra subsp. salzmannii (Dunal) Franco in the lowlands and Pinus mugo subsp. uncinata (Ramond ex DC.) that dominates the highlands. Unfortunately, these species can hardly be distinguished on the basis of their microscopic wood anatomy, so they are grouped under the taxon Pinus sylvestris tp. which refers to all these cryophillous pines that abound in the Mediterranean mountains.

The abundance of Pinus sylvestris tp. wood in certain archaeological records for thousands of years implies an evident limitation in the interpretation of the archaeological record from the point of view of standard wood charcoal analysis. However, the large amount of available fragments from the same taxon also presents an opportunity to apply innovative anthracological and dendro-anthracological tools to the study of these anthracological contexts (Allué et al., 2009; Allué and Mas, 2020; Caruso-Fermé and Théry-Parisot, 2018; Caruso-Fermé et al., 2013; Dufraisse, 2006; Dufraisse and García-Martínez, 2011; Dufraisse et al., 2017; 2020; García-Martínez and 
Dufraisse, 2012; Henry and Théry-Parisot 2014; Paradis-Grenouillet et al., 2013; ThèryParisot et al., 2011; Théry-Parisot and Henry, 2012; Vidal-Matutano et al., 2017).

In this paper, the previously unpublished wood charcoal analysis of the entire archaeological sequence of the Esplugón site (Huesca, NE Iberia) is presented in its regional context. In addition, we introduce the quantitative study of the wood charcoal alterations, as well as the first results of the application of dendro-anthracological tools to wood charcoal fragments, which permit reconstructing which parts of the plants were exploited. For the latter, it has been necessary to create a specific modern dendrological dataset for Scots type pines (Pinus sylvestris tp.) in the south central Pre-Pyrenees. All these approaches enable a better global understanding of forest management by the human inhabitants of the site. The archaeological sequence of Esplugón, including succesive Mesolithic and Neolithic occupations, allows a comparison of fuelwood procurement between the last hunter-gatherers and the first farmers in this region. This work constitutes a starting point for future wood charcoal studies in Pleistocene and Holocene sequences from NE Iberia.

\section{REGIONAL SETTING AND SITE DESCRIPTION}

The southern central Pre-Pyrenees represent a key region for understanding the Mesolithic-Neolithic transition in NE Iberia. The Pyrenean foothills, or Pre-Pyrenees (450-950 m asl), comprise human occupations in rock-shelters and caves, some of them containing long sequences of prehistoric occupation, such as Esplugón, Forcas, Artusia, Aizpea and Arba de Biel sites (Utrilla et al., 2016, Obón et al., 2019; Utrilla and Mazo, 2014; García-Martínez de Lagrán et al, 2017; Barandiarán and Cava, 2001; Montes et al., 2016; Laborda, 2019) (Figure 1). All sites have many similarities as they contain recurrent and probably short-term occupations and they are strategically locatedover the valley, controlling both human and prey movements. Wood charcoal analysis has been recently performed in all of them (Zapata, 2001; Alcolea, 2015; Montes et al., 2016; García-Martínez de Lagrán et al, 2017).

Esplugón is the largest rock-shelter in the southern central Pyrenees known so far for this chrono-cultural period (Figure 2). It is located in the middle transverse corridor of the Guarga valley (Huesca, NE Iberia) between the Pre-Pyrenees and the Pyrenees. The description of six Mesolithic and Neolithic archaeological layers makes it a reference 
site for understanding the Neolithisation process in the Ebro basin (NE Iberia) (Utrilla et al., 2012; 2016; Berdejo and Obón, 2013; Berdejo et al., 2018; Obón et al., 2019). Seven archaeological layers have been identified (numbered 1-7 from top to bottom) organized in 4 chrono-cultural stages of prehistoric occupation (Figure 3):

- Stage 1. Layer 1. A partially disturbed Chalcolithic layer, which contained both Chalcolithic and historical materials.

- Stage 2. Layers 2 and 3 sup. An Early Neolithic (EN) occupation, in which geometric microliths with abrupt retouching was recovered, as well as occasional bone tools and pottery fragments with incised and cardial decorations.

- Stage 3. Layers 3 inf. and 4. A Late Mesolithic (LM) or Geometric Mesolithic occupation, in which a rich lithic assemblage of geometric microliths was recovered, with triangles in the earlier phases and later on trapezes.

- Stage 4. Layers 5 and 6. An Early Mesolithic (EM) occupation which still lacks an accurate chrono-cultural definition. Although the occasional lithic materials recovered seem to fit with a Notches and Denticulate Mesolithic (layer 5) and a Microblade Epipaleolithic (layer 6), the available radiocarbon dates do not support the Epipalaeolithic attribution.

14 radiocarbon dates (Table 1 and Figure 4) place the occupation of the site (excluding Stage 1) between 9.4 and 6.8 ka cal BP (Obón et al., 2019; Laborda, 2019). The Early Mesolithic (EM) stage occurs during the last millennium of the Early Holocene (9.4-8.5 ka cal BP). The start of the Geometric Mesolithic or Late Mesolithic (LM) stage coincides with the 8.4 and 8.2 arid events that give rise to the Middle Holocene in the region (8.5-7.5 ka cal BP). Finally, the Early Neolithic (EN) stage occurs during the Middle Holocene (7.3-6.8 ka cal BP).

Archaeological materials recovered at the site as well as the preliminary archaeozoological results suggest that hunting was the main focus of the settlement throughout the excavated sequence. Recurrent short-term occupations are proposed for the Mesolithic whilemore or less stable, long-term occupations involving various activities (scraping, drilling, mowing) besides hunting, have been proposed for the Neolithic (Utrilla et al., 2016; Obón et al., 2019). In any case, the hunted species are characteristic of a forested environment dominated by red deer (Cervus elaphus), roe deer (Capreolus capreolus), and wild boar (Sus scrofa) (Obón et al., 2019). Despite the presence of some domestic animals only in layer 2 , neither traces related to livestock 
sheltering and feeding nor storage structures have been found so far at the site (Laborda, 2019).

138 Esolugón is located at $800 \mathrm{~m}$ asl. This area is currently characterised by a continental 139 Mediterranean climate with long, dry summers, an average annual temperature between $14012^{\circ} \mathrm{C}$ and $14^{\circ} \mathrm{C}$, and $500 \mathrm{~mm}$ of annual precipitation. The vegetation is characteristic of 141 the transitional zone between the meso-Mediterranean and the oro-Mediterranean 142 biogeographic zones (Rivas Martínez, 1982). Present-day vegetation is influenced by 143 the altitudinal gradient, relief, calcareous lithology and the high levels of human impact. 144 Vegetation around the site is dominated by degraded forest of deciduous Quercus 145 (Quercus faginea Lam. and Quercus cerrioides Wilk \& Costa). Scots pine (Pinus 146 sylvestris L.) and mainly extensive plantations of Austrian pine (Pinus nigra subsp. 147 laricio Maire) grow throughout the valley. Boxwood (Buxus sempervirens L.), 148 hawthorn (Crataegus monogyna Jacq.), dogwood (Cornus sanguinea L.), and brooms 149 (Echinospartum horridum (Vahl) Rothm), grow abundantly in the scrubland and forest edges. The proximity of the Guarga river defines the ample presence of riparian vegetation dominated by black poplar (Populus nigra L.) and willow (Salix eleagnos Scop.).

\section{Materials and methods}

\subsection{Materials.}

157 Archaeological works started in 2009. Specific strategies of sampling and recovery for archaeobotanical remains have been followed at Esplugón site during the 2012, 2013 and 2017 fieldwork seasons. Archaeological layers are characterized by high density and good preservation of charred wood remains. Hand-picking of visible charcoal remains found during fieldwork was accompanied by the wet sieving of all the excavated sediment through a $2-1 \mathrm{~mm}$ mesh. Also, flotation tests with a 0,5-0,25 mm mesh of 20 litres of sediment per square meter and archaeological layer were performed by M. Alcolea in the Laboratory of Prehistory of the University of Zaragoza in 2018. No carpological remains have been found so far in the sampled archaeological deposit. .

166 Charred wood identified in this work corresponds to scattered charcoal in the sediment from samples recovered by hand-picking, wet sieving and flotation. Scattered charcoal is the result of consecutive combustion events reflecting successive collections of 
169 firewood (Chabal, 1997). It constitutes a valuable source of information about the surrounding vegetation of the site and the activities of human groups in the past (Chabal et al., 1999; Théry-Parisot et al., 2010).

\subsection{Methods.}

\subsubsection{Wood charcoal analyses.}

176 Wood charcoal fragments were analysed following the standard methods in 177 anthracology (Vernet, 1973). For the taxonomic identification the wood anatomical 178 features of each fragment were observed along the three anatomical planes under 179 magnifications between x50 and x600, using an incident light dark/bright field Leica 180 DM2700M microscope at the University of Zaragoza (Spain). Botanical identifications 181 were made by reference to wood anatomy atlases (Schweingruber, 1990, García Esteban et al., 2003) and modern carbonized wood reference specimens. Nomenclature follows the guidelines in Tela Botanica (https://www.tela-botanica.org/). No significant differences in the number of identified taxa have been documented from the screened and floated samples.

\subsubsection{Charcoal preservation and condition of wood.}

Charcoal taphonomy in anthracological research provide additional information about plant growth, wood-gathering strategies and combustion and post-deposition processes (Marguerie and Hunot, 2007; Théry-Parisot et al., 2010). In this study 4 relevant features were recorded as absent or present: cell collapse, compression wood, radial cracks and vitrification (Braadbaart and Poole, 2008; McParland et al., 2010; Moskal del Hoyo et al., 2010; Thèry-Parisot and Henry, 2012; Henry and Théry-Parisot, 2014;

194 Vidal-Matutano et al., 2017; Caruso-Fermé and Thèry-Parisot, 2018; Allué and Mas, 2020; Courty et al., 2020). These features in archaeological charcoals provide relevant information about the condition of the procured firewood as well as some conditions of the combustion process. Preservation factors also actually affects wood charcoal stucture preservation and therefore the possibilities in the application of dendroanthracological techniques.

\subsubsection{Dendro-anthracological techniques.}


201 Dendro-anthracological tools allow measuring dendro-anthracological parameters based

202 on morpho-anatomical criteria (Table 2). Dendro-anthracological techniques have been 203 applied on selected Pinus sylvestris tp. wood charcoal fragments with the aid of a 204 multizoom microscope (Nikon AZ100) that allows magnification factors from $\mathrm{x} 4$ to 205 x500 and the NIS Element image analysis software. The measurements are based on the 206 distance and the angle between two ligneous rays. They were obtained by using a semi207 automatic system based on 4 landmarks integrated in the Nikon NIS Elements software. 208 All measurements are taken in transverse (or cross) plane. The selection of fragments was based on two criteria: size and preservation status. In terms of size, a minimum of 4 $\mathrm{mm}^{2}$ is required in transverse (or cross) plane. Regarding the preservation status, the microscopic wood anatomical features must not be deformed, particularly the ligneous rays and the growth ring boundaries.

\subsubsection{1. $\quad$ The pith location tool and wood diameter estimation.}

214 Pinus sylvestris tp. is an appropriate taxon to apply dendro-anthracological techniques. Regarding microscopic wood anatomy features, the presence of visible ligneous rays allow measuring the charcoal pith distance by applying the trigonometric method (Dufraisse and García-Martínez, 2011; Paradis-Grenouillet et al., 2013). It is also important that a modern reference dataset is available for measuring the caliber of pines in the framework of the DENDRAC project (http://dendrac.mnhn.fr/) (Dufraisse et al., 2020). The pith location tool is used to measure the distance between the charcoal fragment and the theoretical location of the missing pith. This tool is based on measurements of the angle and the distance between two ligneous rays and the application of correction factors (Dufraisse and García-Martínez, 2011; Dufraisse et al., 2020). The angle must be $>2$ degrees and the distance $>2 \mathrm{~mm}$ for reducing the margin of error and improving results in dendro-anthracological applications (Dufraisse et al., 2017; 2020). The values were ordered into diameter classes chosen to be compatible with the standards used in dendrometrical plans by foresters: $4 \mathrm{~cm}, 7 \mathrm{~cm}$ and $20 \mathrm{~cm}$ but adding some wood cuts. For conifers diameter classes chosen are [0-2] cm, [2-4] cm, [47] $\mathrm{cm},[7-10] \mathrm{cm},[10-14] \mathrm{cm},[14-20] \mathrm{cm}$ and $>20 \mathrm{~cm}$ (Dufraisse et al., 2017).

232 The Analysis Diameter model has been developed as a tool dedicated to recompose unburnt wood diameter (UWD) in terms of volume based on the distribution of diameter 
234 classes obtained with the pith estimation tool (Dufraisse et al., 2017). It was developed,

235

236

237

238

239

240

241

242

243

244

245

246

247

248

249

250

251

252

253

254

255

256

257

258

259

260

261

262

263

264

265

266 based on the fact (i) burnt, wood undergoes both mass loss and charcoal fragmentation and (ii) a trunk is biologically considered to be a stack of hollow cones whose thickness corresponds to the amplitude of the diameter classes (Dufraisse, 2006; Dufraisse and García-Martínez, 2011). A calculation table provides the respective distribution of these cones in terms of volume (Dufraisse et al., 2020). This model does not reconstruct the original quantity or volume of burnt wood (Dufraisse and García-Martínez, 2011, Dufraisse et al., 2017).

\subsubsection{3. $\quad$ Tree-ring analysis and growth rate.}

Pinus sylvestris tp. wood is characterized in the transverse (or cross) plane by distinct growth ring boundaries (occasionally generating false growth rings in samples from lowlands) and generally abrupt transition from early- (EW) to latewood (LW) (Schweingruber, 1990; Schoch et al., 2004). It makes Pinus sylvestris tp. an appropriate taxon for measuring tree-ring and EW width. Both has been measured in mm with the NIS Element image analysis software (Nikon AZ100). Correction factors have been applied to reverse shrinkage effect in the tree-ring width during charring (GarcíaMartínez and Dufraisse, 2012). The results were plotted by R software (R Core Team, 2017).

In order to establish a discriminating threshold between slow growth rate and fast growth rate we have built a modern dendrological reference dataset in the southern central Pyrenees. Trunks and branches of three Pinus sylvestris L. (and three Pinus nigra subsp. laricio Maire) adult trees between 40 and 50 years old from the Station 1, called Secorún (UTM 30T 734715 469813, 1047 masl), close to Esplugón, were sampled (Figure 1). Our goal was to know the intra-individual variability and establish the existence of different growth patterns between trunk and branches within the same tree. Trunk core discs were sampled at breast height, $1.30 \mathrm{~m}$ above ground, as is standard in dendrochronology. Apical trunks are sampled at an average height of $10.5 \mathrm{~m}$ at which they have a similar diameter to the sampled branches. Four primary branches regularly located along the trunk height have been sampled and measured for each tree. The samples have been measured to the nearest $0.01 \mathrm{~mm}$ with the TSAP-Win program and LINTAB ${ }^{\mathrm{TM}}$ (Rinntech, Heidelberg, Germany) (Rinn, 2011).

\subsubsection{Anthraco-typological classification}


267 The combination of these dendro-anthracological parameters permits the classification

268 of fragments in four anthraco-groups based on the relationship between the estimated 269 minimum diameter and the growth rate (Dufraisse et al., 2017). Following the foresters' 270 diameter ranking, values $<7 \mathrm{~cm}$ were considered to represent branches, and values $>7$ $271 \mathrm{~cm}$ were considered mature or young trunks. This is the threshold used in this work 272 even though in the case of archaeological charcoal fragments, projected diameters $<7$ $273 \mathrm{~cm}$ could correspond to both branches and young individuals (Picornell-Gelabert and 274 Dufraisse, 2018). Regarding growth rate, the threshold between slow growth and fast 275 growth in this work has been established in $1 \mathrm{~mm}$ based on the modern dendrological 276 reference dataset created at the Station 1 Secorún (Figure 5). An anthraco-typological 277 key to sort Pinus sylvestris tp. archaeological charcoal fragments into 4 anthraco-groups 278 is proposed (Figure 6) following Dufraisse et al., 2017 for deciduous oak. Following 279 these assumptions, the anthraco-group 1 corresponds theoretically to the exploitation of 280 branches while anthraco-groups 2, 3 and 4 represent to the exploitation of trunks. The 281 group 2 would correspond to the inner part of the trunk while groups 3 and 4 to the outer part (see also Picornell-Gelabert et al., same volume).

\section{Results}

\subsection{Taxonomic diversity.}

We have studied 1,480 wood charcoal fragments from 6 archaeological layers (Table 3). The presence of 7 taxa has been documented: ash (Fraxinus sp.), juniper (Juniperus sp.), Scots pine type (Pinus sylvestris tp.), deciduous oak (Quercus sp. deciduous), holm oak (Quercus sp. evergreen), and thorny shrubs belonging to the Rosaceae family (Rosaceae/Maloideae and Prunus sp.). The reported percentages of Scots pine type wood vary between 75 and $100 \%$ of the identified fragments in the different archaeological layers (Figure 7). Based on the total number of determined fragments at the site, pine reaches $91 \%$, followed by oak that reaches $6.7 \%$ while the remaining taxa comprise c. $2.3 \%$. The high frequency of pine is common in anthracological assemblages from rockshelters in the region during the entire timespan covered by the Esplugón sampled stratigraphy. 
301

302

303

304

305

306

307

308

309

310

311

312

313

314

315

316

317

318

319

320

321

322

323

324

325

326

327

328

329

330

331

Relevant features recorded in this study: cell collapse, compression wood, radial cracks and vitrification, entail high percentages in the anthracological assemblage of Esplugón (Table 4 and Figure 8). They are common alterations in archaeological charcoals.

Cell collapse is commonly associated with decayed or rotten wood caused by fungi and xylophagous insects (Moskal del Hoyo et al., 2010; Henry and Théry-Parisot, 2014; Vidal-Matutano et al., 2017) or chemical and physical alterations that affect deadwood (Allué and Mas, 2020). A high number of fragments shows signs of fungal degradation, affecting 34.9-58.6\% of pine charcoal fragments. This alteration inhibits the application of dendro-anthracological techniques to fragments in which an important part of the transverse surface is affected by this parameter.

Compression wood is associated with a loss of verticality in stem growth. In mountain environments, it can affect both branches and trunks growing on acute slopes, thus it cannot be used as a discriminating factor. Reaction wood reaches from 25.2 to $69.6 \%$ of the pine charcoal fragments. These fragments have been ommited from dendroanthracological analysis even though correction factors may reduce the influence of offcentred piths (Dufraisse et al., 2017; 2020).

The presence of radial cracks on the transverse plane affects 5.6-20\% of pine charcoal fragments. They are very common in charred wood because of the loss of volatile compounds during the combustion process. Proposed as evidence of the use of green wood as fuel, it has been demonstrated that the occurrence of radial cracks is not correlated with moisture content (Thèry-Parisot and Henry, 2012; Caruso-Fermé and Thèry-Parisot, 2018) being probably important other volatile compounds, e.g. resins, which are common in Scots pines type. Its presence could affect and deform ray distance and angle. Heavily affected pine charcoal fragments have been also omitted from dendro-anthracological analysis.

Finally, vitrification affects $3.2-24.4 \%$ of pine charcoal fragments. It is the main cause of the high number of fragments that could not be determined (classified as undeterminable; see table 3). Although in the current state of the research the causes of this feature are not known (Braadbaart and Poole, 2008; McParland et al., 2010; Courty et al., 2020), it is related to the combustion process. It is especially usual in conifers, probably associated with some specific compounds as resins. . The high presence of 
332 reaction wood, which increases the lignin in tracheid cell walls, a thermoplastic

333 compound, could also favour the vitrification of wood (Alcolea, 2017).

334

335

336

337

338

339

340

341

342

343

344

345

346

347

348

349

350

351

352

353

354

355

356

357

358

359

360

\subsection{Minimum calibres of exploited stems.}

Charcoal preservation and condition of wood have strongly conditioned the application of dendrometric tools. Although only 199 pine charcoal fragments met special requirements of size and preservation status, there are evenly spread across the different phases (Table 5). Both 2 Mesolithic $(n=155)$ and Neolithic $(n=44)$ stages are wellrepresented in the subsample. Trigonometric method has been applied to estimate minimum calibres of exploited firewood. Diameter classes for each stage have been established on the base of minimum diameters of each fragment using pith location tool and wood diameter estimation (Table 5). The UDW has been recomposed using the Analysis Diameter model (ADmodel) (available in https://dendrac.mnhn.fr/spip.php?article237) (Dufraisse et al., 2020).

At the Esplugón site, the exploitation of small calibres predominates throughout the entire archaeological sequence. Minimum diameter classes between 4 and $7 \mathrm{~cm}$ predominate during the 2 Mesolithic stages (EM and LM). During the Early Neolithic (EN) this diameter class diminishes while the diameter classes between 2 and $4 \mathrm{~cm}$ and 7 and $10 \mathrm{~cm}$ gain importance. Above $10 \mathrm{~cm}$ of diameter few fragments have been documented (Table 5). Recomposed percentages (AD\%) reinforce the observed tendency.

Usually, the diameter classes $<7 \mathrm{~cm}$ correspond to branches and/or the inner part of the trunks, and the diameter classes $>7 \mathrm{~cm}$ correspond to the outer part of the trunks (Deleuze et al., 2014). This assertion was tested and confirmed on Pinus halepensis (Picornell et al, same volume). However, the class between 7 and $10 \mathrm{~cm}$ of diameter, considered as a transition, is difficult to classify in this scheme. To discriminate the parts of the exploited stems it is necessary to combine minimum calibres with the growth rate of tree-rings

\subsection{Growth rate.}

Growth rate has been calculated in 199 pine charcoal fragments by measuring growth ring width. A total of 1,788 growth ring width has been measured and the average value 
364 has been calculated to obtain growth rate of each charcoal fragment. Results show calibrated values after applying correction factors (García-Martínez and Dufraisse, 2012).

367

368

369

370

371

372

373

374

375

376

377

378

379

380

381

382

383

384

385

386

387

388

389

390

391

392

393

394

395

No major differences in growth rate have been documented among the different stages (Figure 9). Organizing growth ring width by diameter classes it can be observed that average values are higher in the diametrer classes $>10 \mathrm{~cm}$. Wider growth rings are documented in the 2 to 4 and 4 to $7 \mathrm{~cm}$ diameter classes but they always constitute outlier values (Figure 10).

The results of dendrological analysis of the modern dendrological reference dataset from Secorún show clear intra-individual differences in growth rate between trunks and branches from the same tree and are reproduced in all sampled individuals (Figure 5). According to these data, the threshold between slow and fast growth rate has been established in $1 \mathrm{~mm}$. Archaeological pine charcoal fragments that present average growth ring width values $<1 \mathrm{~mm}$ are considered as slow growth rate and those that present values $>1 \mathrm{~mm}$, as fast growth rate.

\subsection{Anthraco-typological classification: the exploited parts of plants.}

Anthraco-typological classification of the studied anthracological assemblage combines the estimation of the minimum calibres and the growth rate (Dufraisse et al., 2017). The 199 pine wood charcoal fragments have been classified in 4 groups (Table 6). The anthraco-type 1, that theoretically correspond to branches, has the largest number of fragments in the 3 studied stages, reaching almost 80\% during the Early Mesolithic (EM) and 70\% during the Late Mesolithic (LM) and Early Neolithic (EN). The anthraco-types 2, 3 and 4, that theoretically correspond to different parts of the trunk, represent lower percentages, reaching 20\% during the Early Mesolithic (EM) and almost 30\% during the Late Mesolithic (LM) and Early Neolithic (EN).

\section{Firewood procurement in the southern central Pre-Pyrenees during the Early-} Middle Holocene

\subsection{Floristic composition of the forest: taxonomic analyses.}

\subsubsection{Early Mesolithic (9.4-8.5 kyr cal BP)}


During the Early Mesolithic occupation in Esplugón, the Pinus sylvestris tp. is the

397

398

399

400

401

402

403

404

405

406

407

408

409

410

411

412

413

414

415

416

417

418

419

420

421

422

423

424

425

426

427

428 preferred wood for fuel with values reaching up to $90 \%$. Even though extremely high values of conifers persist at the onset of the Holocene in the southern central Pyrenees in both lowland and high altitudes, pollen lake records suggest the rapid spread of mesophytes in the low montane bioclimatic zone, mainly deciduous Quercus, after ca. $9.5 \mathrm{kyr}$ cal BP due to increases in temperature, warmer summers and an increase in water availability (Pérez-Sanz, 2014; González-Sampériz et al., 2017). These are present in the anthracological record of Esplugón in low frequencies. Deciduous and evergreen Quercus hardly represent 3\% of identified wood charcoal fragments in layer 6 and $7 \%$ in layer 5. Shrubby taxa typical of forest edges (Juniperus sp., Prunus sp., Rosaceae/Maloideae) complete the list also reaching low values in the layer 6 and disappearing in layer 5.

Other Pyrenean anthracological sequences show similar patterns: Pinus sylvestris tp. prevails in low montane assemblages until ca. $8.5 \mathrm{kyr}$ cal BP as indicated by the anthracological assemblages from Forcas (Alcolea, 2015), Artusia (García-Martínez de Lagrán, 2017) and the Arba de Biel sites (Montes et al., 2016). At the lowlands, Scots type pine forests are replaced by thermophilous Mediterranean pines from ca. $8.7 \mathrm{kyr}$ cal BP (Alcolea et al., 2017a).

\subsubsection{Late Mesolithic (8.5-7.5 kyr cal BP)}

After $8.2 \mathrm{kyr}$ cal BP pollen lake records indicate that semi-deciduous and evergreen Quercus replaced mesophytes in the lowlands and low montane (González-Sampériz et al., 2017). Simultaneously, these deciduous forests replaced pinewoods also in the high montane and subalpine bioclimatic zones (Plà and Catalán, 2005; González-Sampériz et al., 2005; Pérez-Sanz et al., 2013) indicating a relevant increase in winter temperatures and a shift in the precipitation regime with a more evenly distributed rainfall (Magny et al., 2002; Morellón et al., 2009).

Pinus sylvestris tp. persists as the most consumed wood for fuel in Esplugón during its Late Mesolithic occupation in layers 4 and 3 inf. between 8.5 and $7.5 \mathrm{kyr}$ cal BP. Accompanying taxa are basically the same as in the previous period and they do not reach $10 \%$ of wood charcoal fragments. The only novelty is the presence of riparian 
vegetation represented by a single charcoal fragment of ash (Fraxinus sp.). This resilient tendency of low montane pine forests in the southern central Pyrenees is also supported by the anthracological records of Forcas (Alcolea, 2015) and Arba de Biel sites (Montes et al., 2016). On the contrary, the human use of widespread deciduous forest is welldocumented in south eastern Pyrenean deposits (Zapata and Peña-Chocarro, 2005; RuízAlonso and Zapata, 2017).

\subsubsection{Early Neolithic (7.3-6.8 kyr cal BP)}

Despite the chronological gap in the sequence suggested by radiocarbon dating (7.5-7.3 kyr cal BP) Pinus sylvestris tp. continues being the most consumed wood for fuel in Esplugón, reaching up to $90 \%$ in layer 3 sup. and $75 \%$ in layer 2. On the contrary, Pinus sylvestris tp. has completely disappeared in the eastern Pyrenean sequences at $7.3 \mathrm{kyr}$ cal BP, mainly replaced by deciduous Quercus and yew (Taxus baccata) accompanied by shrubby taxa (Ruíz-Alonso and Zapata, 2017). The Neolithic deposit of Esplugón just start showing a trend towards the use of deciduous taxa in layer 2, dated to $6.8 \mathrm{kyr}$ cal BP, where deciduous Quercus reaches almost $20 \%$ accompanied by all the aforementioned taxa. Resilience of Scots type pinewoods at Esplugón is supported by other wood charcoal analyses in southern central Pyrenees from the low montane (Heinz y Vernet, 1995; Alcolea, 2015; Alcolea et al., 2017b; Montes et al., 2016) to the subalpine bioclimatic zones (Obea et al., 2011; Obea, 2014) at least until 6 kyr cal BP. The limited presence of other taxa in the anthracological record could be related to the structure of pine forests with low shrubby undergrowth (Allué et al., 2018).

\subsection{Structure of the forest: dendro-anthracological insights.}

\subsubsection{The exploited parts of plants.}

Pinus sylvestris tp. is the main taxon exploited for fuel throughout the archaeological sequence of Esplugón and also in other short-term human occupations in rockshelters, like Forcas (Alcolea, 2016) and the Arba de Biel sites (Montes et al., 2016) suggesting that this woody taxon is the most available in the immediate vicinity of the sites. Even though the resilience of Scots type pine forests has been proposed in some inland regions of Mediterranean Iberia until ca. 7.7 kyr cal BP (Rubiales et al., 2010; Aranbarri et al., 2014) or even during the whole Middle Holocene (8.2-4.2 kyr cal BP) (Franco 
461 Múgica et al., 2001; 2005) due to the delayed onset of the interglacial conditions based on high continentality, water shortage and absence of well-developed soil (Carrión et al., 2010), regional pollen data in the southern central Pyrenees point to a retreat of Scots type pine forests from $9.5 \mathrm{kyr}$ cal BP, more evident after $7.3 \mathrm{kyr}$ cal BP (González-Sampériz et al., 2017). Wood charcoal analysis at Chaves (7.6-7.0 kyr cal

466

467 BP) reveals the use of a broad spectrum of woody taxa as expected in a long-term settlement where diversified human activities took place (Utrilla and Laborda, 2018). Although Scots type pine is the most consumed taxon it only reaches $30 \%$ at level $\mathrm{Ib}$ (7.6-7.3 kyr cal BP) (Alcolea et al., 2017b).

Regarding the parts of exploited plants, no big differences have been documented between the different stages of human occupation. The use of branches, between 70$80 \%$, prevails over the use of trunks, between $20-30 \%$ throughout the entire archaeological sequence (Figure 11). The arrival of the Neolithic does not introduce a change in forest management strategies. This is consistent with the documented uses of the rockshelter. The main human activity is always the hunting of the forest wild species like roe deer (Capreolus capreolus), red deer (Cervus elaphus) and wild boar (Sus scrofa) (Obón et al., 2019). Domestic animals are restricted to layer 2 and neither storage structures nor stabling layers implying chages in the site function have been found (Laborda, 2019).

\subsubsection{Scots type pine forests exploitation as fuel.}

The three native species of cryophillous montane pines growing in NE Iberia are normally grouped in the taxon Pinus sylvestris tp. Montane Iberian pines include Pinus sylvestris L., Pinus mugo subsp. uncinata (Ramond ex DC.) Domin, Pinus nigra subsp. salzmannii (Dunal) Franco. Theoretically they grow nowadays at different altitudes in NE Iberia: Pinus nigra between 500 and 800 masl, Pinus sylvestris between 800 and $1700 \mathrm{~m}$ a.s.l. and Pinus uncinata above 1800 masl (Costa et al., 2001), but usually they overlap biogeographically and can interbreed (Quézel and Médail, 2003). These trees do not show differences in wood anatomy allowing to identify each of them (Greguss, 1955; Schweingruber, 1990) so its past distribution at species level is not well-known (Roiron et al., 2013 Allué et al., 2018). Likewise, is not possible to know if our deposits 
493 contain more than one species of Scots type pine. In any case, they share

494 biogeographical parameters and tree architecture.

495 We propose that the architecture of Scots type pines strongly influences their use as 496 firewood. The architecture of the tree is characteristic of each species and allows to 497 understand its growth strategy and occupation of the space. Scots type pine trees present 498 a monopodial structure composed of a single stem or trunk that reaches up to thirty 499 metres. The trunk is generally straight but it can present alterations due to the ecological 500 conditions of its growth (strong winds, the weight of the snow, the extreme dryness or 501 slope angle). The primary branches grow in polycyclic crowns, formed annually at the same level around the trunk parallel to each other and displaying similar calibres. These trees are characterized by a strong apical dominance, meaning that the branches develop more slowly than the trunk (Riou-Nivert, 2001).

Scots type pine forests have a pyramidal or conical shape when young, which nevertheless changes with age. The silouette of adult trees can vary depending on whether they grow isolated or in groups (Figure 12). When they grow isolated generally green branches reach the foot of the tree. When they grow in groups, these trees exert competition over each other at two levels: (i) in the soil, which affects their radical underground system, and (ii) in the air, which affects their radical air system, that is, the branches. In the first case, they "run away" from each other, moving as far as possible to take advantage of soil moisture, giving rise in general to open forests. In the second case, they "run away" seeking to reach a greater height to have more access to light. The growth in population provides a lateral shelter, that results in thinner branches and a reduced growth in diameter of the trunk (Riou-Nivert, 2001). In this case, the lower branches under cover usually die due to lack of light. There is very little physiological connection between branches and trunk (Shigo et al., 1987). When they are no longer functional, a resinous partition isolates them to protect the trunk from infections. The branch becomes parasitic and stops participating in the life of the tree. When the process of decomposition by microorganisms is advanced the branch falls according to the phenomenon known as branch shedding (or natural pruning). This observation is supported by the high percentages of decayed wood documented in the record (Figure

523 8), which are associated with the use of deadwood as fuel (Allué et al., 2009; Henry and 524 Thèry-Parisot, 2014; Vidal Matutano et al., 2017).Different palaeoenvironmental and cultural factors has been previosly proposed in the preferential use of Pinus sylvestris 
526

527

528

529

530

531

532

533

534

535

536

537

538

539

540

541

542

543

544

545

546

547

548

549

550

551

552

553

554

555

556

557

558

tp. as fuelwood by European hunter-gatherer groups. The significant mobility of human groups, resulting in seasonal occupations of the sites, and a relatively limited tool kit would undoubtedly have had an impact on firewood procurement. A marked preference for deadwood procurement optimally ensures the supply during short-term occupations while green wood, which must be cut and dried over several months, is more suited to long-term occupations. Combustion properties largely depend on the condition (dead or living, dry or green) and morphological (size and diameter) state of wood more than species (Allué et al., 2009; Henry and Thèry-Parisot, 2014; Thèry-Parisot et al., 2016; 2018; Vidal Matutano et al., 2017). Also, specific functions of the sites could influence choices underlying the collection of wood, as is the case of Chauvet-Pont d'Arc, where Scots pine type is selected to provide light and produce charcoal for use in rockart motifs (Thèry-Parisot and Thiebault, 2005, Théry-Parisot et al., 2018).

Our hypothesis is that the selection of Scots type pine wood in Mesolithic-Neolithic transition Pyrenean sequences could be related to its capacity to produce a large amount of dead biomass, almost dry, easy to gather, and more or less regular in size and diameter, resulting in a certain overrepresentation of this taxon in seasonal or temporary settlements in rockshelters located in the low montane southern central Pyrenees (Figure 13). Apart from small calibre branches, probably related to the branch shedding of defunct branches, the discrete presence of the largest diameter classes suggests the consumption of trunks as well (Figure 14). This does not necessarily imply that live trees were felled for firewood use. Scots type pine forests tend to alternate live trees with dead trees (Costa et al., 2001), so dry trunks that remain standing for years could be easily cut down by prehistoric groups. Forest expansion attested from ca. $9.5 \mathrm{kyr}$ cal BP and changes in fire regimes (González-Sampériz, 2004; Gil-Romera et al., 2014) could have resulted in a higher biomass availability.

\section{Conclusions and perspectives}

Summing up, wood charcoal analysis at Esplugón reveals that Scots type pines (Pinus sylvestris tp.) is the most consumed firewood along the entire archaeological sequence. Although deciduous Quercus appears from the base of the sequence its use as fuel is always secondary. These results match those from other studies in low montane rockshelters containing long sequences of human occupation during the MesolithicNeolithic in the southern central Pyrenees. 
559 The recurrent observation of anatomical wood decay features suggests the main use of

560 deadwood as fuel. First dendro-anthracological results suggest the large use of branches

561 and sometime trunks along the whole archaeological sequence. Small calibre branches

562 are more abundant in the record, probably related to branch shedding of defunct

563 branches. The discrete presence of the largest diameter classes points to the

564 consumption of trunks, possibly taking advantage of the fact that Pinus sylvestris L.

565 forests frequently alternate live and dry trees.

566

567 No important changes in forest management have been documented between the last hunther-gatherers and the first farmers at Esplugón, neither in terms of species nor of the exploited parts of plants. So, we propose that there was continuity in the patterns of firewood gathering as domestic fuel across the successive short-term occupations of the rockshelter mainly dedicated to the hunting of forest species despite the appearance of

572 the first domesticated elements with the arrival of the Neolithic.

574 Finally, the application of dendro-anthracological tools to NE Iberia is novel. The development of this research line applied to Mesolithic-Neolithic transition and more recent archaeological contexts as well as to different taxa could be key for understanding different uses of wood, fuelwood procurement and forest management.

\section{Acknowledgements}

580 This study agrees with the objectives to the project Luz e calor na cova. Uso $y$ aprovechamiento del combustible vegetal por parte de las sociedades cazadorasrecolectoras y primeras productoras del norte de Iberia. M. Alcolea is funded by a Post-Doc Grant from Xunta de Galicia mod. A (Ref. ED481B 2018/016). The funding

584 of the research has been possible thanks to the R+D Project HAR 2017-85023-P Gaps

585 and sites. Vacíos y ocupaciones en la Prehistoria de la Cuenca del Ebro funded by the

586 Ministry of Economy and Competitivity (Spain) and the research group 587 PRESAGE/CNRS UMR 7209 Archéozoologie, Archéobotanique: Sociétés, Pratiques et 588 Environnements (National Museum of Natural History, France). The authors 589 acknowledge the heads of the archaeological excavation, P. Utrilla (University of 590 Zaragoza, PPVE Reasearch Group), A. Berdejo and A. Obón (De la Roca al Metal 591 independent research Group), the access to archaeobotanical materials. The authors 
592 acknowledge M. Lemoine (MNHN) their assistance in dendro-anthracological data

593 curation. We also would like to specially thank the guest editor, Eleni Asouti, the 594 invitation to participate in this special issue.

Figure and table captions

\section{$599 \quad$ Figures}

600 Figure 1. Location of the Esplugón site (Huesca, Spain), the Station 1 sampled for 601 modern dendrological reference (Secorún) and the main surrounding archaeological 602 sites mentioned in the text. Base: MDT200 IGN (Spanish Government).

603 Figure 2. Location of the rock-shelter in relation with their current biogeographical 604 framework. Photographs: J.L. Peña and C. Mazo (University of Zaragoza).

605 Figure 3. West-east stratigraphic profile from the Esplugón site according to Laborda, 6062019.

607 Figure 4. Plotted dates 14C-AMS cal BP from the Esplugón site and GRIP climate 608 curve according to Obón et al., 2019.

609 Figure 5. Boxplot showing tree-ring width analysis results in the modern dendrological 610 reference dataset Secorún. PINI Pinus nigra, PISY Pinus sylvestris. (Rn) Total values 611 from branches, (T1) Values from 1.30 height trunks, (T2) Values from apical trunks, 612 (Tn) Total values from trunks.

613 Figure 6. Anthraco-typological key to sort Pinus sylvestris tp. archaeological charcoal 614 fragments into 4 anthraco-groups. Based in Dufraisse et al., 2017 for deciduous oaks.

Figure 7. Anthracological diagram from the Esplugón site (Huesca, NE Iberia).

617 Figure 8. Condition of wood at the charcoal assemblage from Esplugón by a binomial 618 system based on presence or absence. The percentages of alteration are calculated in 619 relation to the total number of studied fragments. (EM) Early Mesolithic, (LM) Late 620 Mesolithic, (EN) Early Nolithic.

621 Figure 9. Boxplots showing tree-ring width analysis results in the Esplugón site. Results 622 organized by chronological periods: (EM) Early Mesolithic, (LM) Late Mesolithic, (N) 623 Early Neolithic.

624 Figure 10. Boxplots showing tree-ring width analysis results in the Esplugón site. 625 Results organized by diametre classes.

626 Figure 11. Evolution of the parts of plants exploited at the Esplugón site.

627 Figure 12. Architecture of Pinus sylvestris L. depending on whether it grew isolated 628 (left) or in population (right) according to Riou-Nivert, 2001, 107. 
Figure 13. Current vegetation around Esplugón. A. Map based on Forest Map of Spain MFE50 MITECO, black star marks the site location. B. Deadwood accumulated in the Guarga riverbanks because of the presence of large blocks of limestone. July of 2013. C. Pinus sylvestris L. currently growing next to the site. Photographs: M. Alcolea.

Figure 14. Diagrams summarizing the results of the application of dendroanthracological tools to wood charcoal fragments in the Esplugón site. At left, diametric classes obtained by trigonometric method expressed in percentages by fragments and corrected recomposed percentages by ADmodel (available in https://dendrac.mnhn.fr/spip.php?article237). At right, measured fragments grouped in anthraco-groups based in anthraco-typological key showed in Figure 6. The results are grouped in chronocultural periods.

\section{$\underline{\text { Tables }}$}

Table 1. Radiocarbon dating from the Esplugón site in chronological order (OxCal v 4.3.2. IntCal13, Reimer et al., 2013; Bronk Ramsey, 2017). In italics, the dates which are not in agreement with its stratigraphic position, interpreted as intrusions due to bioturbations.

Table 2. Table summarizing applied dendrometric techniques according to Dufraisse et al., same volume.

Table 3. Absolute and relative frequencies of the taxa identified in the Esplugón site. (EM) Early Mesolithic, (LM) Late Mesolithic, (EN) Early Neolithic.

Table 4. Anatomical alterations identified in the Esplugón charcoal assemblage by a binomial system based on presence or absence. The percentages of alteration are calculated in relation to the number of charcoal fragments identified as Pinus sylvestris tp. except in the case of vitrification, calculated in relation to the total number of studied fragments. (EM) Early Mesolithic, (LM) Late Mesolithic, (EN) Early Nolithic.

Table 5. Diameter classes of charcoal fragments analysed by dendrometric techniques at Esplugón site. AD\% = \% corrected recomposed. (EM) Early Mesolithic, (LM) Late Mesolithic, (EN) Early Neolithic.

Table 6. Anthraco-groups to which charcoal fragments analysed at the Esplugón site belong according Dufraisse et al., 2017. (1) Diameter $<7$ and growth rate $<1 \mathrm{~mm}$, (2) diameter $<7$ and growth rate $>1 \mathrm{~mm}$, (3) diameter $>7$ and growth rate $>1 \mathrm{~mm}$, (4) diameter $>7$ and growth rate $>1 \mathrm{~mm}$. (EM) Early Mesolithic, (LM) Late Mesolithic, (EN) Early Neolithic.

\section{Reference list}

Alcolea, M. 2015. La secuencia antracológica de Forcas II (Graus, Huesca) y su contribución al conocimiento de la evolución paleoambiental holocena del Prepirineo central. Saldvie 15, 53-63. 
667 Alcolea, M. 2017. Mesolithic fuel use and woodland in the Middle Ebro Valley (NE 668 Spain) through wood charcoal analysis. Quat. Int., 431, 39-51.

669 Alcolea, M., Domingo, R. Piqué, R., Montes, L. 2017a. Landscape and firewood at 670 Espantalobos mesolithic site (Huesca, Spain). First results. Quat. Int., 457, 198-210

671 Alcolea, M., Utrilla, P., Piqué, R., Laborda, R., Mazo, C. 2017b. Fuel and acorns: Early

672 Neolithic plant use from Cueva de Chaves (NE Spain). Quat. Int., 457, 228-239.

673 Alcolea, M., 2018. Donde hubo fuego: estudio de la gestión humana de la madera como 674 recurso en el valle del Ebro entre el Tardiglaciar y el Holoceno Medio. Vol. 53. Prensas 675 Universitarias. University of Zaragoza.

676 Allué, E., Euba, I., Solé, A. 2009. Charcoal taphonomy: the study of the cell structure 677 and surface deformations of Pinus sylvestris type for the understanding of formation 678 processes of archaeological charcoal assemblages. Journal of Taphonomy, 7(2-3), 5767972.

680 Allué, E., Martínez-Moreno, J., Alonso, N. Mora, R. 2012. Changes in the vegetation 681 682 and human management of forest resources in mountain ecosystems at the beginning of MIS 1 (14.7-8 ka cal BP) in Balma Guilanyà (Southeastern Pre-Pyrenees, Spain). C.R. 683 Palevol, 11, 507-518

Allué, E., Solé, A., Burguet-Coca, A. 2017a. Fuel exploitation among Neanderthals based on the anthracological record from Abric Romaní (Capellades, NE Spain) Quat. Int., 431, 6-15

Allué, E., Picornell-Gelabert, L., Daura, J., Sanz, M. 2017b. Reconstruction of the palaeoenvironment and anthropogenic activity from the Upper Pleistocene/Holocene anthracological records of the NE Iberian Peninsula (Barcelona, Spain) Quat. Int., 457, 172-189

691

Allué, E., Martínez-Moreno, J., Roy, M., Benito-Calvo, A., Mora, R. 2018. Montane 692 pine forests in NE Iberia during MIS 3 and MIS 2. A study based on new 693 anthracological evidence from Cova Gran (Santa Linya, Iberian Pre-Pyrenees). Rev. Palaeobot. Palynol., 258, 62-72 markers in Palaeolithic sites in NE Iberia. J. Archaeol. Sci. Rep., 30, 102231. 
697 Aranbarri, J., González-Sampériz, P., Valero-Garcés, B., Moreno, A., Gil-Romera, G., 698 Sevilla-Callejo, M., García-Prieto, E., Di Rita, Mata, M.P., Morellóne, M., Magri, D., 699 Rodríguez-Lázaro, J., Carrión, J.S. 2014. Rapid climatic changes and resilient 700 vegetation during the Lateglacial and Holocene in a continental region of south-western 701 Europe. Glob. Planet. Change, 114, 50-65.

702 Aura, J.E., Carrión, Y., Estrelles, E., Jorda, G.P. 2005. Plant economy of hunter703 gatherer groups at the end of the last Ice Age: plant macroremains from the cave of 704 Santa Maira (Alacant, Spain) ca. 12000-9000 BP. Veget. Hist. Archaeobot., 14(4), 542705550.

706 Badal, E. 1992. L'anthracologie préhistorique: à propos de certains problèmes 707 méthodologiques. Bulletin de la société botanique de France. Actualités Botaniques, $708 \quad 139(2-4), 167-189$

709 Badal, E., Carrión, Y., Figueiral, I., Rodríguez-Ariza, M.O. 2012a. Pinares y enebrales. 710 El paisaje solutrense en Iberia. Espacio Tiempo y Forma. Serie I, Prehistoria y 711 Arqueología, 1(5).

712 Badal, E., Villaverde, V., Zilhao, J. 2012b. Middle Palaeolithic wood charcoal from 713 three sites in south and West Iberia. Biogeographical implication. Sagvntvm Extra 13, $714 \quad 13-24$.

715 Badal, E, Martínez-Varea, C. 2018. Different parts of the same plants. Charcoals and 716 seeds from Cova de les Cendres (Alicante, Spain). Quat. Int., 463, 391-400.

717 Barandiarán, I., Cava, A. 2002. Cazadores-recolectores en el Pirineo navarro. El sitio de 718 Aizpea entre 8000 y el 6000 años antes de ahora. Veleia, 10.

719 Berdejo, A., Obón, A. 2013. Un nuevo yacimiento neolítico en las sierras exteriores del 720 Pirineo central: el Esplugón (Villobas). Bolskan, 2, 139-144.

721 Berdejo, A., Obón, A., Utrilla, P., Laborda, R., Sierra, A., Alcolea, M., Bea, M., 722 Domingo, R. 2018. El abrigo de El Esplugón (Molino de Billobas-Sabiñánigo, Huesca). 723 Un ejemplo de la transición Mesolítico/Neolítico en el prepirineo oscense. In J.M. 724 Rodanés, J.I. Lorenzo (eds.): Actas del II Congreso de Arqueología y Patrimonio 725 Aragonés, 29-40. 
Braadbaart, F., Poole, I. 2008. Morphological, chemical and physical changes during charcoalification of wood and its relevance to archaeological contexts. J. Archaeol. Sci. $35,2434-2445$.

Bronk Ramsey, C. 2017. OxCal Program, Version 4.3. Oxford Radiocarbon Accelerator Unit. University of Oxford.

Carrión, J.S., Finlayson, C., Fernandez, S., Finlayson, G., Allué, E., López-Sáez, J.A., López-Garcia, P., Gil-Romera, G., Bailey, G., González-Sampériz, P. 2008. A coastal reservoir of biodiversity for Upper Pleistocene human populations: palaeoecological investigations in Gorham's Cave (Gibraltar) in the context of the Iberian Peninsula. Quat. Sci. Rev. 27, 2118-2135.

Carrión, J.S., Fernández, S., González-Sampériz, P., Gil-Romera, G., Badal, E., Carrión, Y., López-Merino, L., López-Sáez, J.A., Fierro, E., Burjachs, F. 2010. Expected trends and surprises in the Lateglacial and Holocene vegetation history of the Iberian Peninsula and Balearic Islands. Rev. Palaeobot. Palynol., 162, 458-475.

Carrión, Y., Calatayud, P. G., Eixea, A., Martínez-Varea, C.M., Tormo, C., Badal, E., Zilhao, J., Villaverde, V. 2019. Climate, environment and human behaviour in the Middle Palaeolithic of Abrigo de la Quebrada (Valencia, Spain): The evidence from charred plant and micromammal remains. Quat. Sci. Rev., 217, 152-168.

Caruso-Fermé, L., Huerta, R., Théry-Parisot, I. 2013. ¿Recolectar o cortar?: modalidades de adquisición del material leñoso en cazadores-recolectores de Patagonia. In A. Zangrando, R. Barberena, A. Gil, G. Neme, M. Giardina, L. Luna, C. Otaola, S. Paulides, L. Salgán, A. Tívoli (eds.): Tendencias teórico-metodológicas y casos de estudio en la arqueología de la Patagonia. Museo de Historia Natural de San Rafael and INAPL, 281-287.

Caruso-Fermé, L., Théry-Parisot, I. 2018. The shrinkage cracks and the diameter of the log: an experimental approach towards fuel management by patagonian hunter-gatherer (Paredón Lanfré site Río Negro Province, Argentina). Archaeol. Anthropol. Sci., 10(7), 1821-1829

Chabal, L. 1997 Forêts et sociétés en Languedoc (Néolithique final, Antiquité tardive): l'anthracologie, méthode et paléoécologie. Documents d'Archéologie Française, 63, Maison des Sciences de l'Homme, Paris. 
757 Chabal, L. Fabre, L. Terral, J.F. Théry-Parisot, I. 1999. L'Anthracologie. La Botanique.

758 Ed. Errance, París, pp. 43-104.

759 Costa, M., Morla, C., Sainz, H. 2001. Los bosques ibéricos. Una interpretación 760 geobotánica. Ed. Planeta. Madrid.

761 Courty, M.A., Allué, E., Henry, A. 2020. Forming mechanisms of vitrified charcoals in 762 archaeological firing- assemblages. J. Archaeolog. Sci. Rep., 30, 102215.

763 Deleuze, C., Monreau, F., Renaud, J.P., Vivien, Y., Rivoire, M., Santenoise, Ph., 764 Longuetaud, F., Mothe, F., Hervé, J.C., Vallet, P. 2014. Estimer le volume total d'un 765 arbre, quelles que soient l'essence, la taille, la sylviculture, la station. RDV Tech. ONF, $76644,22-32$.

767 Dufraisse, A. 2006. Charcoal anatomy potential, wood diameter and radial growth. In 768 A. Dufraisse (ed.): Charcoal analysis: new analytical tools and methods for archaeology. 769 Papers from the Table Ronde held in Basel 2004. BAR International Series, 1483, 47$770 \quad 59$.

771 Dufraisse, A., García-Martínez, M.S. 2011. Mesurer les diamètres du bois de feu en 772 anthracologie. Anthropobotanica, 1, 1-18.

Dufraisse, A., Coubray, S., Girardclos, O., Nocus, N., Lemoine, M., Dupouey, J. L., \& Marguerie, D. 2017. Anthraco-typology as a key approach to past firewood exploitation and woodland management reconstructions. Dendrological reference dataset modelling with dendro-anthracological tools. Quat. Int., 463, 232-249.

Dufraisse, A., Bardin, J., Picornell-Gelabert, L., Coubray, S., García-Martínez, M.S., Lemoine, M., Vila, S. 2020. Pith location tool and wood diameter estimation: Validity and limits tested on seven taxa to approach the length of the missing radius on archaeological wood and charcoal fragments. J. Archaeol. Sci. Rep., 29, 102166.

Franco-Múgica, F., Gómez-Manzaneque, F., Maldonado, J., Morla, C., Sainz-Ollero, H. 2001. The Holocene history of Pinnus forests in the Spanish northern meseta. The Holocene, 11(3), 343-358.

784 Franco-Múgica, F., García-Antón, M., Maldonado-Ruiz, J., Morla, C., Sainz, H. 2005.

785 Ancient pine forest on inland dunes in the Spanish northern meseta. Quat. Res., 63(1), 786 $1-14$. 
787 García-Esteban, L., Guindeo-Casasus, A., Peraza-Oramas, C., de Palacios, P. 2003. La madera y su anatomía. Anomalías y defectos, estructura microscópica de coníferas y frondosas, identificación de maderas, descripción de especies y pared celular. Ed. Mundi-Prensa. Madrid.

García-Martínez, M.S., Dufraisse, A., 2012. Correction factors on archaeological Wood diameter estimation. Sagvntvm Extra 13, 283-290.

García-Martínez de Lagrán, I., Iriarte, E., García-Gazólaz, J., Tejedor, C., Gibaja, J. F., Moreno-García, M., Pérez-Jordá, G., Ruíz-Alonso, M., Sesma, J., Garrido-Pena, R., Carrancho, A., Peña-Chocarro, L., Rojo, M. 2016. 8.2 ka BP paleoclimatic event and the Ebro Valley Mesolithic groups: Preliminary data from Artusia rock shelter (Unzué, Navarra, Spain). Quat. Int., 403, 151-173.

Gil-Romera, G., González-Sampériz, P., Lasheras, L., Sevilla-Callejo, M., Moreno, A., Valero-Garcés, B., López-Merino, L., Carrión, J.S., Pérez-Sanz, A., Aranbarri, J., García-Prieto, E. 2014. Biomass-modulated fire dynamics during the last glacialinterglacial transition at the Central Pyrenees (Spain). Paleogeogr. Paleoclimatol. Paleoecol., 402, 113-124.

803

González-Sampériz, P. 2004. Evolución paleoambiental del sector central de la cuenca 804 del Ebro durante el Pleistoceno superior y Holoceno. Instituto Pirenaico de Ecología. 805 Zaragoza.

806 González-Sampériz, P., Valero-Garcés, B., Carrión, J.S., Peña-Monné, J.L., García807 Ruiz, J.M., Martí Bono, C. 2005. Glacial and Lateglacial vegetation in northeastern 808 Spain: new data and a review. Quat. Int., 140, 4-20.

González-Sampériz, P., Aranbarri, J., Pérez-Sanz, A., Gil-Romera, G., Moreno, A., Leunda, M., Sevilla-Callejo, M., Corella, J.P., Morellón, M., Oliva, B., Valero-Garcés,

811 B. 2017. Environmental and climate change in the southern Central Pyrenees since the 812 Last Glacial Maximum: A view from the lake records. Catena, 149, 668-688.

813 Greguss, P. 1955. Identification of Living Gymnosperms on the Basis of Xylotomy. 814 Akadémiai Kiado. Budapest.

815 Heinz, C., Vernet, J.L. 1995. Analisi antracologica dels nivells mesolítics i del neolític 816 antic de la Balma de la Margineda. Paleoecologia i relacions home-vegetació. En J. 
817 Guilaine, M. Martzluff (eds.): Les excavacions a la Balma de la Margineda (1979-

818 1991). Serie Prehistoria d'Andorra 3. Govern d'Andorra, 26-64.

819 Henry, A., I. Théry-Parisot, 2014. From Evenk campfires to prehistoric hearths:

820 charcoal analysis as a tool for identifying the use of rotten wood as fuel J. Archaeol.

821 Sci., 52 (2014), pp. 321-336.

822 Laborda, R. 2019. El Neolítico antiguo en el Valle Medio del Ebro. Una visión desde la 823 cerámica y las dataciones radiocarbónicas. Prensas Universitarias. University of 824 Zaragoza.

825 Magny, M., Miramont, C., Sivan, O. 2002. Assessment of the impact of climate and 826 anthropogenic factors on Holocene Mediterranean vegetation in Europe on the basis of 827 palaeohydrological records. Paleogeogr. Paleoclimatol. Paleoecol, 186(1-2), 47-59.

828 Marguerie, D., Hunot, J. Y. 2007. Charcoal analysis and dendrology: data from 829 archaeological sites in north-western France. J. Archaeol. Sci., 34(9), 1417-1433.

830 Mazo, C., Alcolea, M. 202019. New data concerning Neanderthal occupation in the 831 Iberian System: First results from the late Pleistocene (MIS 3) Aguilón P5 cave site (NE 832 Iberia). Quat. Int., 551, 105-122.

McParland, L., Collinson, M.E., Scott, A.C., Campbell, G., Veal, R. 2010. Is vitrification in charcoal a result of high temperature burning of wood? J. Archaeol. Sci., 37(10), 2679-2687.

Montes, L., Domingo, R., González-Sampériz, P., Sebastián, M., Aranbarri, J., 837 Castaños, P., Alcolea, M, García-Simón, L.M., Laborda, R. (2016). Landscape, 838 resources and people during the Mesolithic and Neolithic times in NE Iberia: The Arba de Biel Basin. Quat. Int., 403, 133-150.

840 Moskal-del Hoyo, M., M. Wachowiak, R.A. Blanchette. Preservation of fungi in archaeological charcoal. J. Archaeol. Sci., 37 (9) (2010), pp. 2106-2116. Morellón, M., Valero-Garcés, B., Vegas-Vilarrúbia, T., González-Sampériz, P., 843 Romero, O, Delgado-Huertas, A., Mata, P., Moreno, A., Rico, M., Corella, J.P. 2009. 844 Lateglacial and Holocene palaeohydrology in the western Mediterranean region: the 845 Lake Estanya record (NE Spain). Quat. Sci. Rev., 28(25-26), 2582-2599. 
846

847

848

849

850

851

852

853

854

855

856

857

858

859

860

861

862

863

864

865

866

867

868

869

870

871

872

873

874

875

876

Obea, L. 2014. El paisaje neolítico: un estudio preliminar de los restos antracológicos de Coro Trasito (Tella). In I. Clemente, E. Gassiot, J. Rey, (eds.): Sobrarbe antes de Sobrarbe. Pinceladas de historia de los Pirineos. Centro de estudios de Sobrarbe, 43-54.

Obea, L., Piqué, R., Martin, M., Gassiot, E. 2011. The exploitation of forest resources in mountain areas during the Neolithic in the northeast of the Iberian Peninsula. Sagvntvm Extra 11, 129-130.

Obón, A., Berdejo, A., Laborda, R., Sierra, A., Alcolea, A., Bea, M., Domingo, R., Utrilla, P. 2019. L'abri de L'Esplugón (Villobas-Sabiñánigo, Huesca, Espagne): apports des données à la question de la transition Mésolithique-Néolithique dans les PréPyrénées centrales. In M. Deschamps, S. Costamagno, P.Y. Milcent, J.-M. Pétillon, C. Renard, N. Valdeyron (dirs.): La conquête de la montagne: des premières occupations humaines à l'anthropisation du milieu. Éditions du Comité des travaux historiques et scientifiques, 1-24.

Paradis-Grenouillet, S., Dufraisse, A., Allée, P. 2013. Tree ring curvature measures and wood diameter: comparison of different imaging techniques. In F. Damblon (ed.): IVe International Meeting of Anthracology (Bruxelles, septembre 2008). BAR International Series, 173-182.

Plà, S., Catalán, J., 2005. Chrysophyte cysts from lake sediments reveal the submillennial winter/spring climate variability in the northwestern Mediterranean region throughout the Holocene. Clim. Dyn. 24, 263-278.

Pérez-Sanz, A. 2014. Holocene climate, vegetation and human impact in the Western Mediterranean inferred from Pyrenean lake records and climate models. Unpublished PhD. University of Zaragoza.

Pérez-Sanz, A., González-Sampériz, P., Moreno, A., Valero, B., Gil-Romera, G., Rieradevall, M., Tarrats, P., Lasheras, L., Morellón, M., Belmonte, A., Sancho, C. 2013. Holocene climate variability, vegetation dynamics and fire regime in the central Pyrenees: the Basa de la Mora sequence (NE Spain). Quat. Sci. Rev., 73, 149-169.

Picornell-Gelabert, L., Dufraisse, A. 2018. Wood for Building: Woodland Exploitation for Timber Procurement in the Prehistoric and Protohistoric Balearic Islands (Mallorca and Menorca; Western Mediterranean). Environ. Archaeol., https://doi.org/10.1080/14614103.2018.1521086. 
877 Quézel, P., Médail, F. 2003. Ecology and biogeography of Mediterranean Basin forests.

878 Ed. Elsevier. Paris.

879 R Core Team (2017). R: A language and environment for statistical computing. R 880 Foundation for Statistical Computing, Vienna, Austria. https://www.R-project.org/.

881 Reimer, P.J., Bard, E., Bayliss, A., Beck, J.W., Blackwell, P.G., Ramsey, C.B., Buck, 882 C.E., Cheng, H., Edwards, R.L., Friedrich, M., Grootes, P.M., Guidelson, T.P., 883 Haflidason, H., Hajdas, I., Hatté, C., Heaton, T.J., Hoffmann, D.L., Hogg, A.G., 884 Hughen, K.A., Kaiser, K.F., Kromer, B., Manning, S.W., Niu, M., Reimer, R.W., 885 Richards, D.A., Scott, E.M., Southon, J.R., Staff, R.A., Turney, C.S.M., van del Plicht, 886 J. 2013. IntCal13 and Marine13 radiocarbon age calibration curves 0-50,000 years cal 887 BP. Radiocarbon, 55(4), 1869-1887.

888 Rinn, F., 2011. TSAP-Win. Time Series Analysis and Presentation for 889 Dendrochronology and Related Applications. User Ref. 110. www.rinntech.com.

890 Riou-Nivert, P. 2001. Les résineux. Institut pour le dévelopement forestier. Paris

891 Rivas-Martínez, S. 1982. Étages bioclimatiques, secteurs chorologiques et séries de 892 végetation de le Espagne méditerranéenne. Ecología Mediterránea, VIII(1/2), 275-288.

893 Roiron, P., Chabal, L. Figueiral, I., Terral, J.F., Ali, A. 2013. Palaeobiogeography of 894 Pinus nigra Arn. subsp. salzmannii (Dunal) Franco in the north-western Mediterranean 895 Basin: a review based on macroremains. Rev. Palaeobot. Palynol., 194, 1-11.

896 Rubiales, J.M., García-Amorena, I., Hernández, L., Génova, M., Martínez, F., 897 Manzaneque, F.G., Morla, C. 2010. Late Quaternary dynamics of pinewoods in the 898 Iberian Mountains. Rev. Palaeobot. Palynol., 162, 476-491 .

899 Ruíz-Alonso, M., Zapata, L. 2017. Transformation and human use of forests in the 900 Western Pyrenees during the Holocene based on archaeological wood charcoal. Quat. 901 Int., 364, 86-93.

902 Schoch, W., Heller, I., Schweingruber, F.H., Kienast, F. 2004. Wood anatomy of central 903 European Species. Online version: www.woodanatomy.ch. 
905 Shigo, A.L., Vollbrecht, K., Hvass, N. 1987. Biologie et soins de l'arbre: guide 906 photographique. Ed. IDF. Paris.

907 Théry-Parisot, I. 2001. Economie des combustibles au paléolithique: expérimentation, 908 taphonomie, anthracologie. Dossiers de documentation archéologique 20. CNRS 909 Editions. Paris

910 Théry-Parisot, I., 2002. Gathering of firewood during the Palaeolithic In S. Thiébault 911 (ed.): Charcoal analysis, methodological approaches, palaeoecological results and wood 912 uses. BAR International Series, 1063, 242-249.

913 Théry-Parisot, I., Henry, A. 2012. Seasoned or green? Radial cracks analysis as a 914 method for identifying the use of green wood as fuel in archaeological charcoal. J. 915 Archaeol. Sci., 39(2), 381-388.

916 Théry-Parisot, I., Thiébault, S. 2005. Le pin (Pinus sylvestris): préférence d'un taxon ou 917 contrainte de l'environnement? Etude des charbons de bois de la Grotte Chauvet. 918 Bulletin de la société préhistorique française, 102(1), 69-75.

919 Théry-Parisot, I., Chabal, L., Chrzavzez, J. 2010. Anthracology and taphonomy, from 920 wood gathering to charcoal analysis. A review of the taphonomic processes modifying 921 charcoal assemblages, in archaeological contexts Palaeogeogr. Palaeoclimatol. 922 Palaeoecol., 291(1-2), 142-153.

923 Théry-Parisot, I., Dufraisse, A., Chzrazvzez, J., Henry, A., Paradis-Grenouillet, S. 2011. 924 Charcoal analysis and wood diameter: inductive and deductive methodological 925 approaches for the study of firewood collecting practices. Sagvntvm Extra 11, 31-32.

926 Théry-Parisot, I., Henry, A., Chrzazvez, J. 2016. Apport de l'expérimentation à la 927 compréhension des pratiques en anthracologie: gestion et utilisation du bois de feu dans 928 les sociétés préhistoriques. Cadernos do LEPAARQ, 13(25), 511-536.

929 Théry-Parisot, I., Thiébault, S., Delannoy, J. J., Ferrier, C., Feruglio, V., Fritz, C., Gely, 930 B., Guibert, P., Monney, J., Tosello, G., Clottes, J., Geneste, J.M. 2018. Illuminating the 931 cave, drawing in black: wood charcoal analysis at Chauvet-Pont d'Arc. Antiquity, 932 92(362), 320-333.

933 Utrilla, P., Laborda, R. 2018. La Cueva de Chaves (Bastarás, Huesca): 15000 años de 934 ocupación prehistórica. Trabajos de Prehistoria, 75(2), 248-269. 
935 Utrilla, P., Mazo, C. 2014. La Peña de las Forcas (Graus, Huesca): Un asentamiento

936 estratégico en la confluencia del Ésera y el Isábena. Prensas Universitarias. University 937 of Zaragoza.

938 Utrilla, P., Berdejo, A., Obón, A. 2012. El Esplugón: un gran abrigo mesolítico en el 939 valle del Guarga (Huesca). In J.R. Muñiz-älvarez (coord.): Ad Orientem. Del final del 940 Paleolítico en el norte de España a las primeras civilizacions del Oriente Próxim: 941 Estudios En Homenaje A Juan Antonio Fernández-Tresguerres. University of Oviedo, $942 \quad 235-251$.

943 Utrilla, P., Berdejo, A., Obón, A., Laborda, R., Domingo, R., Alcolea, M. 2016. El 944 abrigo de El Esplugón (Billobas-Sabiñánigo, Huesca). Un ejemplo de transición 945 Mesolítico-Neolítico en el Prepirineo central. In H. Bonet (coord.): Del Neolític a l'Edat 946 del Bronze en el Mediterrani occidental. Estudis en homenatge a Bernat Martí Oliver. 947 Museu de Prehistòria de València, 75-96.

948 Vernet, J.L. 1973. Étude sur l'histoire de la végétation du Sud-Est de la France au 949 Quaternaire d'après l'étude des charbons de bois principalement. Paléobiologie 950 continentale, 4, 1-90.

951 Vernet, J.L. 1997. L'homme et la forêt méditerranéenne: de la Préhistoire à nos jours. Ed. Errance. Paris.

953 Vidal-Matutano, P. 2017. Firewood and hearths: Middle Palaeolithic woody taxa 954 distribution from El Salt, stratigraphic unit Xb (Eastern Iberia). Quat. Int., 457, 74-84.

955 Vidal-Matutano, P., Hernández, C.M., Galván, B., Mallol, C. 2015. Neanderthal 956 firewood management: evidence from stratigraphic unit IV of Abric Del Pastor (Eastern 957 Iberia) Quat. Sci. Rev., 111, 81-93.

958 Vidal-Matutano, P., Henry, A., Théry-Parisot, I. 2017. Dead wood gathering among 959 Neanderthal groups: charcoal evidence from Abric del Pastor and El Salt (Eastern 960 Iberia). J. Archaeol. Sci., 80, 109-121.

961 Vidal-Matutano, P., Pérez-Jordà, G., Hernández, C.M., Galván, B. 2018. 962 Macrobotanical evidence (wood charcoal and seeds) from the Middle Palaeolithic site 963 of El Salt, Eastern Iberia: Palaeoenvironmental data and plant resources catchment areas 964 J. Archaeolog. Sci. Rep., 19, 454-464. 
965 Zapata, L., 2001. El uso de los recursos vegetales en Aizpea (Navarra, Pirineo 966 Occidental): la alimentación, el combustible y el bosque. In I. Barandiarán, A. Cava

967 (eds.): Cazadores-recolectores en el Pirineo navarro: el sitio de Aizpea entre 8.000 y $968 \quad 6.000$ BP. Veleia, 10, 325-359.

969 Zapata, L., Peña-Chocarro, L. 2005. Los macrorrestos vegetales del yacimiento de 970 Mendandia. In Alday, A. (ed.): El campamento prehistórico de Mendandia: ocupaciones 971 mesolíticas y neolíticas entre el 8500 y el 6400 B.P. Diputación Foral de Álava. Vitoria, $972 \quad 411-425$. 
Journal Pre-proof

\begin{tabular}{|c|c|c|c|c|c|}
\hline $\begin{array}{c}\text { Sample } \\
\text { type }\end{array}$ & Lab. Ref. & Date BP & Date 2s cal BP & $\begin{array}{c}\text { Archaeological } \\
\text { Layer }\end{array}$ & Phase \\
\hline Bone & Beta 338509 & $5970 \pm 30$ & $6893-6731$ & 3 sup & EN \\
\hline Bone & Beta 283899 & $6120 \pm 40$ & $7159-6903$ & 4 & EN \\
\hline Bone & MAMS 30169 & $6166 \pm 23$ & $7163-6997$ & 6 & $E N$ \\
\hline Bone & MAMS 30168 & $6282 \pm 22$ & $7259-7170$ & 3 sup & LM \\
\hline Bone & Beta 313517 & $6730 \pm 40$ & $7668-7514$ & 3 inf & LM \\
\hline Bone & MAMS 30166 & $6781 \pm 23$ & $7670-7588$ & 2 & LM \\
\hline Bone & Beta 306723 & $6950 \pm 50$ & $7926-7681$ & 3 inf & LM \\
\hline Bone & MAMS 30167 & $7355 \pm 23$ & $8291-8044$ & 4 & LM \\
\hline Charcoal & GrA 59632 & $7620 \pm 40$ & $8519-8366$ & 4 & LM \\
\hline Charcoal & GrA 59634 & $7715 \pm 45$ & $8585-8419$ & 6 & LM \\
\hline Bone & Beta 306725 & $7860 \pm 40$ & $8934-8547$ & 5 & EM \\
\hline Charcoal & GrA 59633 & $8015 \pm 45$ & $9021-8717$ & 5 & EM \\
\hline Bone & Beta 306722 & $8380 \pm 40$ & $9486-9300$ & 6 & EM \\
\hline
\end{tabular}


Journal Pre-proof

\begin{tabular}{|l|l|l|}
\hline $\begin{array}{l}\text { Dendro-anthracological } \\
\text { parameter }\end{array}$ & $\begin{array}{l}\text { Morpho-anatomical } \\
\text { criteria }\end{array}$ & $\begin{array}{l}\text { Dendro-anthracological } \\
\text { tools }\end{array}$ \\
\hline Growth rate & Tree-ring width & $\begin{array}{l}\text { Dendrometry by image } \\
\text { analysis software }\end{array}$ \\
\hline Minimum diameter & $\begin{array}{l}\text { Convergence of ligneous } \\
\text { rays }\end{array}$ & $\begin{array}{l}\text { Pith location tool and wood } \\
\text { diameter estimation } \\
\text { Analysis Diameter model } \\
\text { (ADmodel) }\end{array}$ \\
\hline
\end{tabular}


Journal Pre-proof

\begin{tabular}{|c|c|c|c|c|c|c|c|c|c|c|c|c|}
\hline Layer & \multirow{2}{*}{\multicolumn{2}{|c|}{$\begin{array}{c}6 \\
\mathrm{EM}\end{array}$}} & \multirow{2}{*}{\multicolumn{2}{|c|}{\begin{tabular}{|c|}
5 \\
EM
\end{tabular}}} & \multirow{2}{*}{\multicolumn{2}{|c|}{$\begin{array}{c}4 \\
L M\end{array}$}} & \multirow{2}{*}{\multicolumn{2}{|c|}{$\frac{3 \text { inf }}{L M}$}} & \multirow{2}{*}{\multicolumn{2}{|c|}{$\frac{3 \text { sup }}{\text { EN }}$}} & \multirow{2}{*}{\multicolumn{2}{|c|}{$\begin{array}{c}2 \\
\text { EN }\end{array}$}} \\
\hline Chronology & & & & & & & & & & & & \\
\hline Taxa & $\mathbf{n}$ & $\%$ & $\mathbf{n}$ & $\%$ & $\mathbf{n}$ & $\%$ & $\mathbf{n}$ & $\%$ & $\mathbf{n}$ & $\%$ & $\mathbf{n}$ & $\%$ \\
\hline Fraxinus sp. & - & - & - & - & 1 & 0.5 & - & - & - & - & 4 & 1.7 \\
\hline Juniperus sp. & 3 & 1.3 & - & - & - & - & - & - & - & - & 1 & 0.4 \\
\hline Pinus sylvestris tp. & 222 & 93.7 & 193 & 92.7 & 194 & 99 & 216 & 96.9 & 220 & 90.5 & 183 & 76.6 \\
\hline Prunus sp. & 2 & 0.8 & - & - & 1 & 0.5 & - & - & - & - & 2 & 0.8 \\
\hline Quercus sp. deciduous & 4 & 1.7 & 13 & 5.7 & - & - & 6 & 2.7 & 23 & 9.5 & 44 & 18.4 \\
\hline Quercus coccifera/ilex & 3 & 1.3 & 3 & 1.4 & - & - & - & - & - & - & 2 & 0.8 \\
\hline Rosaceae/Maloideae & 3 & 1.3 & - & - & - & - & 1 & 0.4 & - & - & 3 & 1.3 \\
\hline Total determinable & 237 & & 208 & & 196 & & 223 & & 243 & & 239 & \\
\hline Undeterminable & 7 & 2.9 & 28 & 11.9 & 54 & 21.6 & 27 & 10.8 & 7 & 2.8 & 11 & 4.4 \\
\hline Total & 244 & & 236 & & 250 & & 250 & & 250 & & 250 & \\
\hline
\end{tabular}


Journal Pre-proof

\begin{tabular}{|c|c|c|c|c|c|c|c|c|c|c|c|c|}
\hline Layer & \multicolumn{2}{|c|}{6} & \multicolumn{2}{|c|}{5} & \multicolumn{2}{|c|}{4} & \multicolumn{2}{|c|}{3 inf } & \multicolumn{2}{|c|}{3 sup } & \multicolumn{2}{|c|}{2} \\
\hline Chronology & \multicolumn{2}{|c|}{ EM } & \multicolumn{2}{|c|}{ EM } & \multicolumn{2}{|c|}{ LM } & \multicolumn{2}{|c|}{ LM } & \multicolumn{2}{|c|}{ EN } & \multicolumn{2}{|c|}{ EN } \\
\hline Alterations & $\mathbf{n}$ & $\%$ & $\mathbf{n}$ & $\%$ & $\mathbf{n}$ & $\%$ & $\mathbf{n}$ & $\%$ & $\mathbf{n}$ & $\%$ & $\mathbf{n}$ & $\%$ \\
\hline Cells collapse & 117 & 52.7 & 81 & 41.9 & 79 & 40.7 & 104 & 48.1 & 129 & 58.6 & 64 & 34.9 \\
\hline Compession wood & 111 & 50 & 83 & 59.7 & 135 & 69.6 & 146 & 67.6 & 88 & 40 & 46 & 25.2 \\
\hline Radial cracks & 44 & 19.8 & 21 & 10.8 & 34 & 17.5 & 26 & 5.6 & 44 & 20 & 18 & 9.8 \\
\hline Total Pinus & 222 & 100 & 193 & 100 & 194 & 100 & 216 & 100 & 220 & 100 & 183 & 100 \\
\hline Vitrification & 14 & 5.7 & 28 & 11.9 & 61 & 24.4 & 31 & 12.4 & 8 & 3.2 & 14 & 5.6 \\
\hline Total fragments & 244 & 100 & 236 & 100 & 250 & 100 & 250 & 100 & 250 & 100 & 250 & 100 \\
\hline
\end{tabular}


Journal Pre-proof

\begin{tabular}{|l|c|c|c|c|c|c|c|c|c|}
\hline Chronology & \multicolumn{3}{|c|}{ EM } & \multicolumn{3}{c|}{ LM } & \multicolumn{3}{c|}{ EN } \\
\hline Diameter class & n & \% & AD\% & n & \% & AD\% & n & \% & AD\% \\
\hline $0-2 \mathrm{~cm}$ & 3 & 4.5 & 0 & 7 & 8.0 & 0 & 2 & 4.5 & 0 \\
\hline $2-4 \mathrm{~cm}$ & 27 & 40.3 & 32.3 & 32 & 36.4 & 31.3 & 21 & 47.7 & 46.6 \\
\hline $4-7 \mathrm{~cm}$ & 26 & 38.8 & 42.4 & 33 & 37.5 & 47.4 & 11 & 25 & 20.0 \\
\hline $7-10 \mathrm{~cm}$ & 8 & 12.0 & 19.8 & 9 & 10.2 & 14.6 & 7 & 15.9 & 25.8 \\
\hline $10-14 \mathrm{~cm}$ & 1 & 1.5 & 1.8 & 5 & 5.7 & 2.1 & 1 & 2.8 & 1.8 \\
\hline $14-20 \mathrm{~cm}$ & 1 & 1.5 & 2.3 & 2 & 2.8 & 4.7 & 1 & 2.8 & 3.2 \\
\hline$>20 \mathrm{~cm}$ & 1 & 1.5 & 1.4 & 0 & 0 & 0 & 1 & 2.8 & 2.7 \\
\hline Total & $\mathbf{6 7}$ & $\mathbf{1 0 0}$ & $\mathbf{1 0 0}$ & $\mathbf{8 8}$ & $\mathbf{1 0 0}$ & $\mathbf{1 0 0}$ & $\mathbf{4 4}$ & $\mathbf{1 0 0}$ & $\mathbf{1 0 0}$ \\
\hline
\end{tabular}


Journal Pre-proof

\begin{tabular}{|c|c|c|c|c|c|c|}
\hline Chronology & \multicolumn{2}{|c|}{ EM } & \multicolumn{2}{c|}{ LM } & \multicolumn{2}{c|}{ EN } \\
\hline Anthraco-type & n & \% & n & \% & n & \% \\
\hline 1 & 53 & 79.1 & 62 & 70.5 & 31 & 70.5 \\
\hline 2 & 3 & 4.5 & 10 & 11.4 & 3 & 6.8 \\
\hline 3 & 8 & 11.9 & 16 & 18.2 & 10 & 22.7 \\
\hline 4 & 3 & 4.5 & 0 & 0 & 0 & 0 \\
\hline Total & $\mathbf{6 7}$ & $\mathbf{1 0 0}$ & $\mathbf{8 8}$ & $\mathbf{1 0 0}$ & $\mathbf{4 4}$ & $\mathbf{1 0 0}$ \\
\hline
\end{tabular}




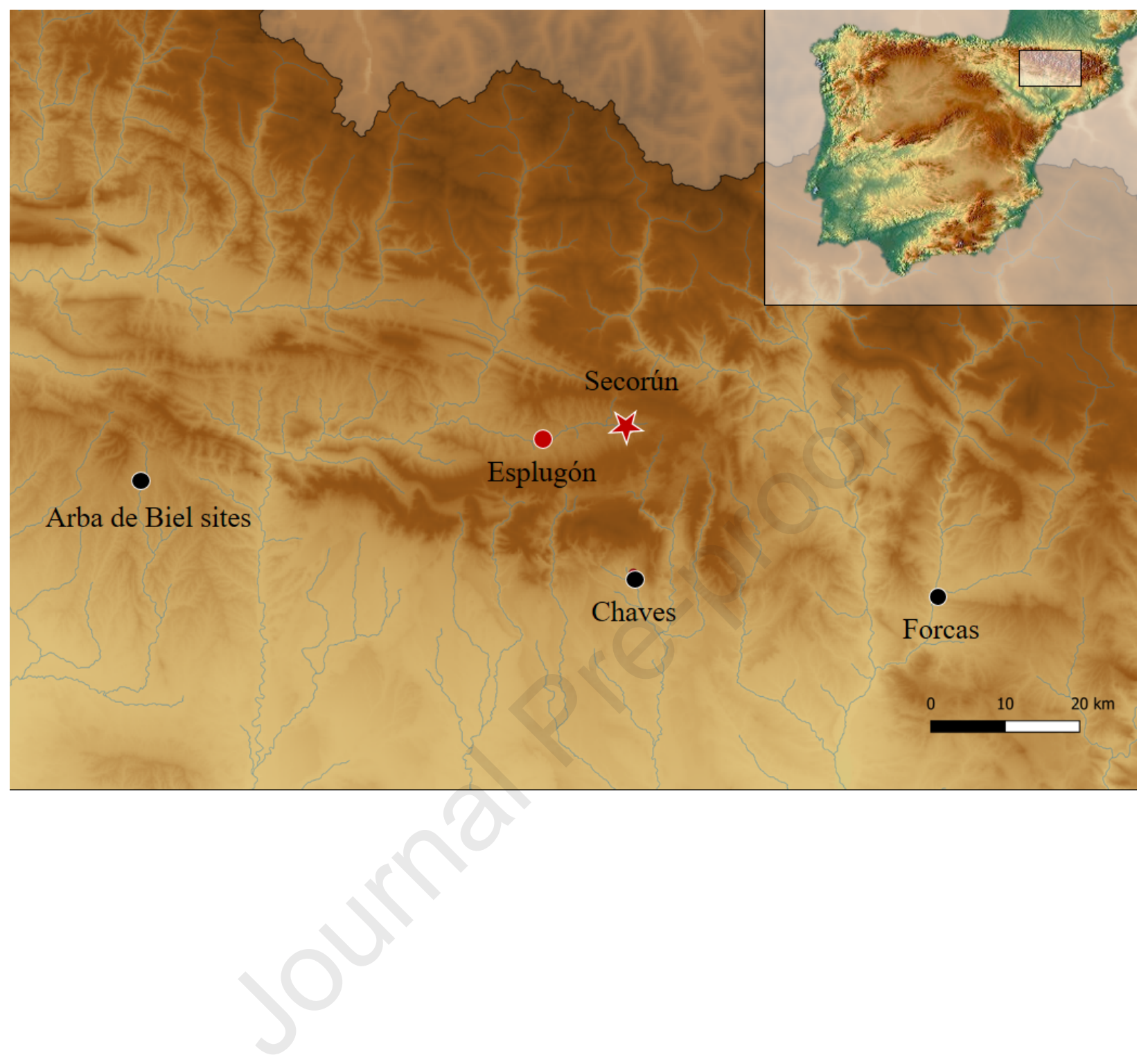




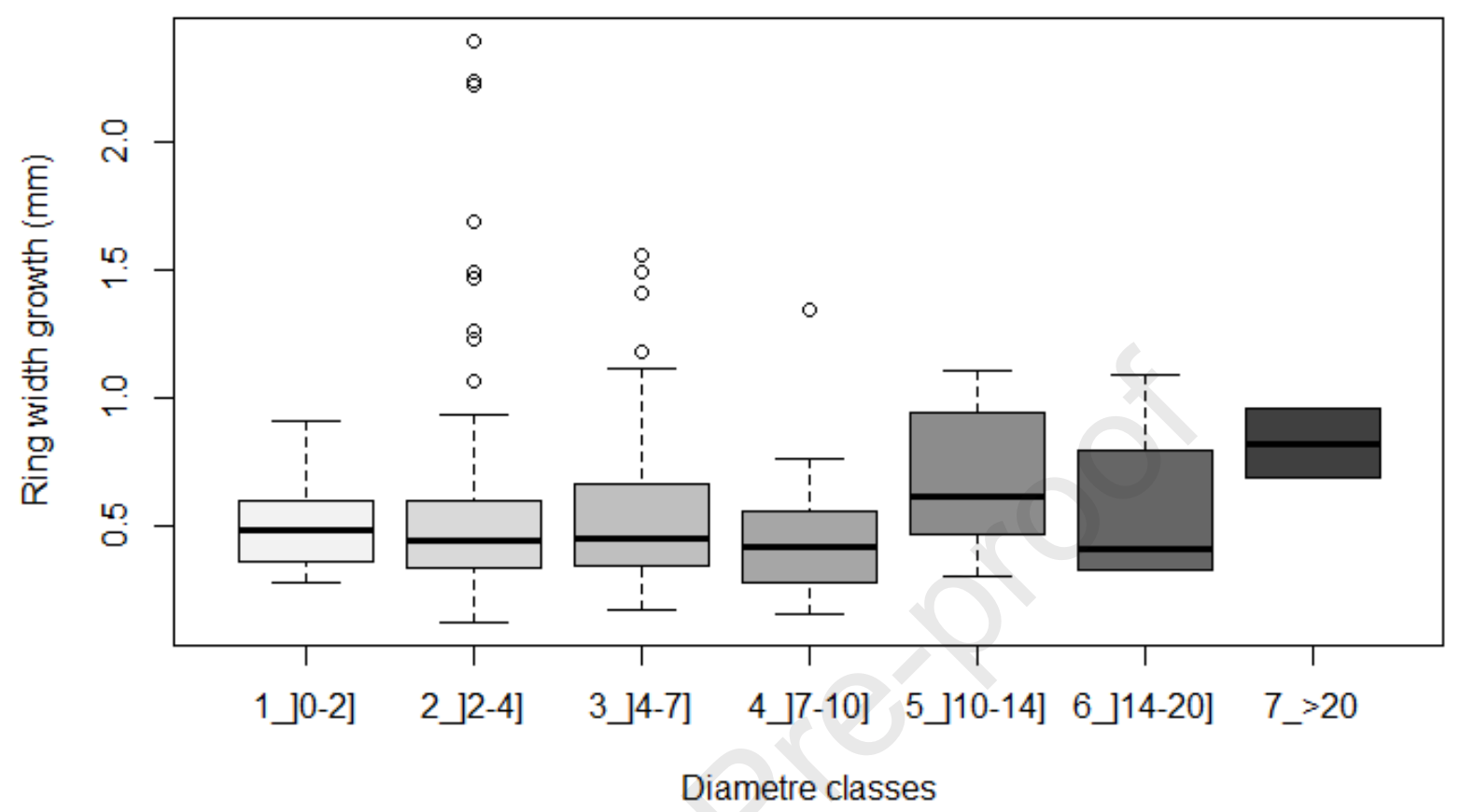




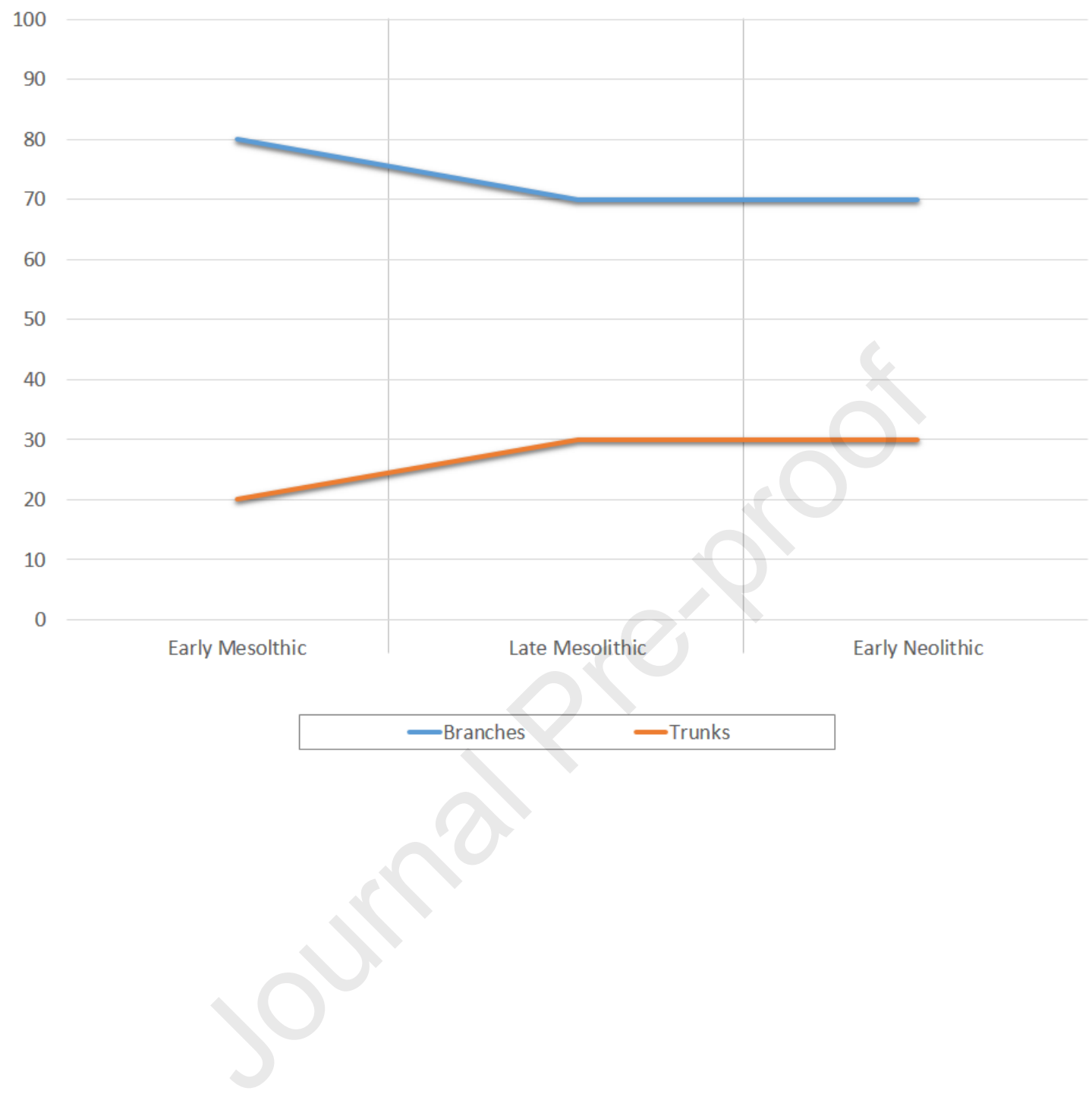




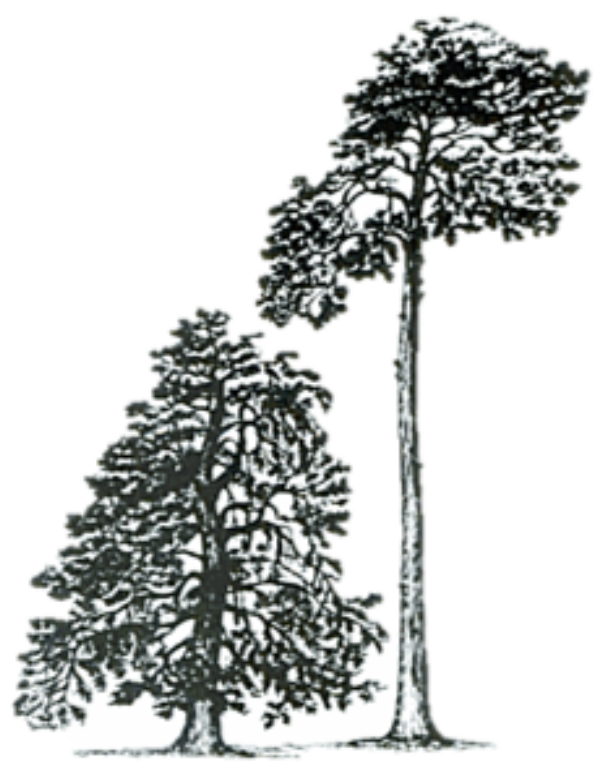




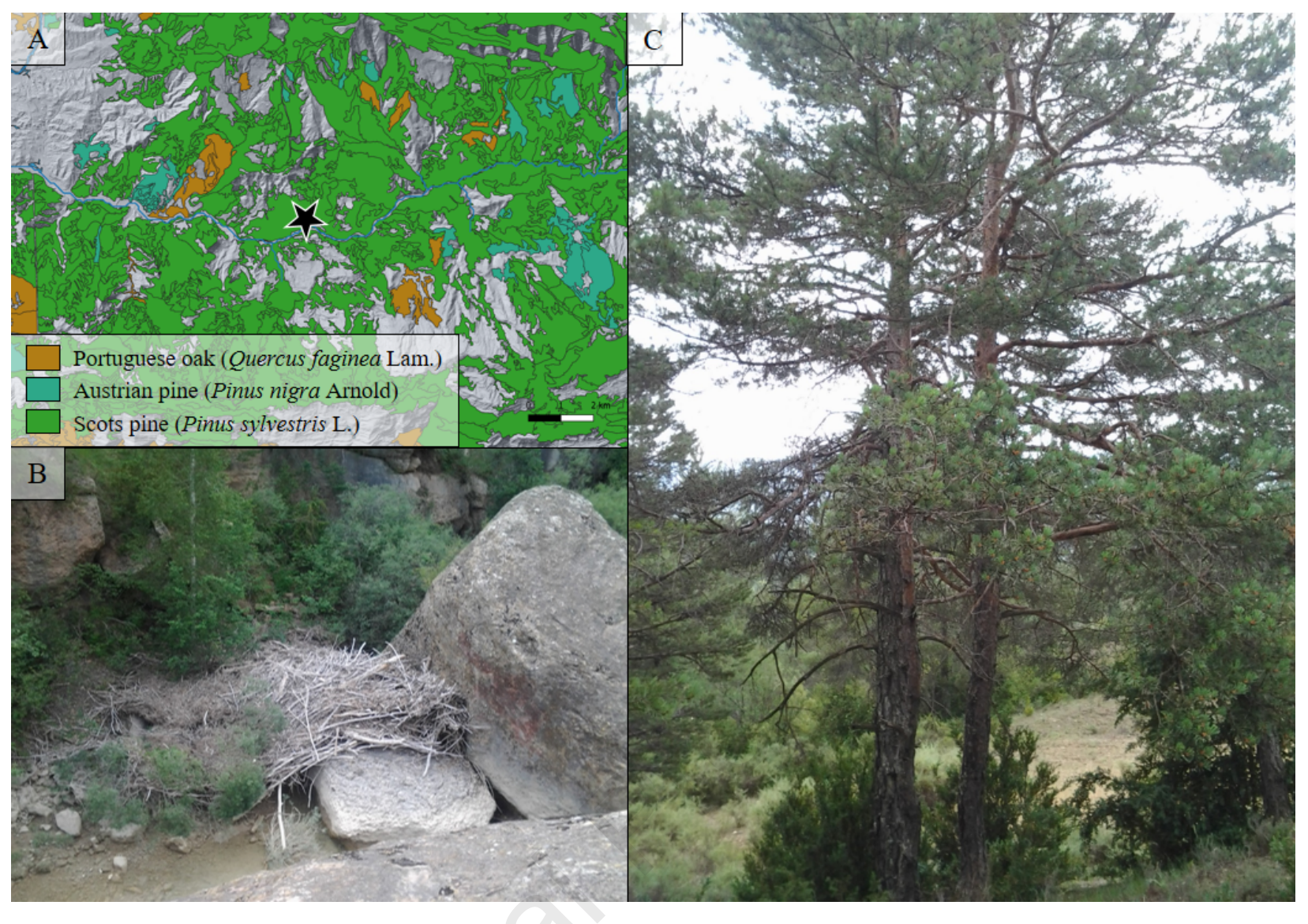



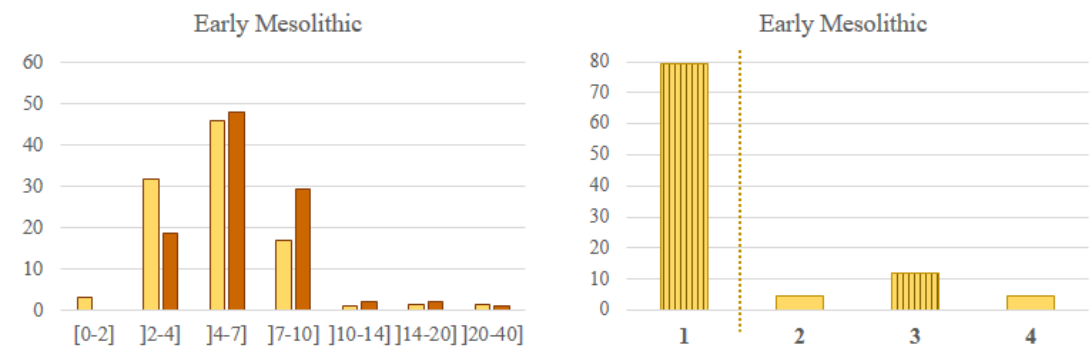

$\square$ charcoal \% $\square$ corrected recomposed \%
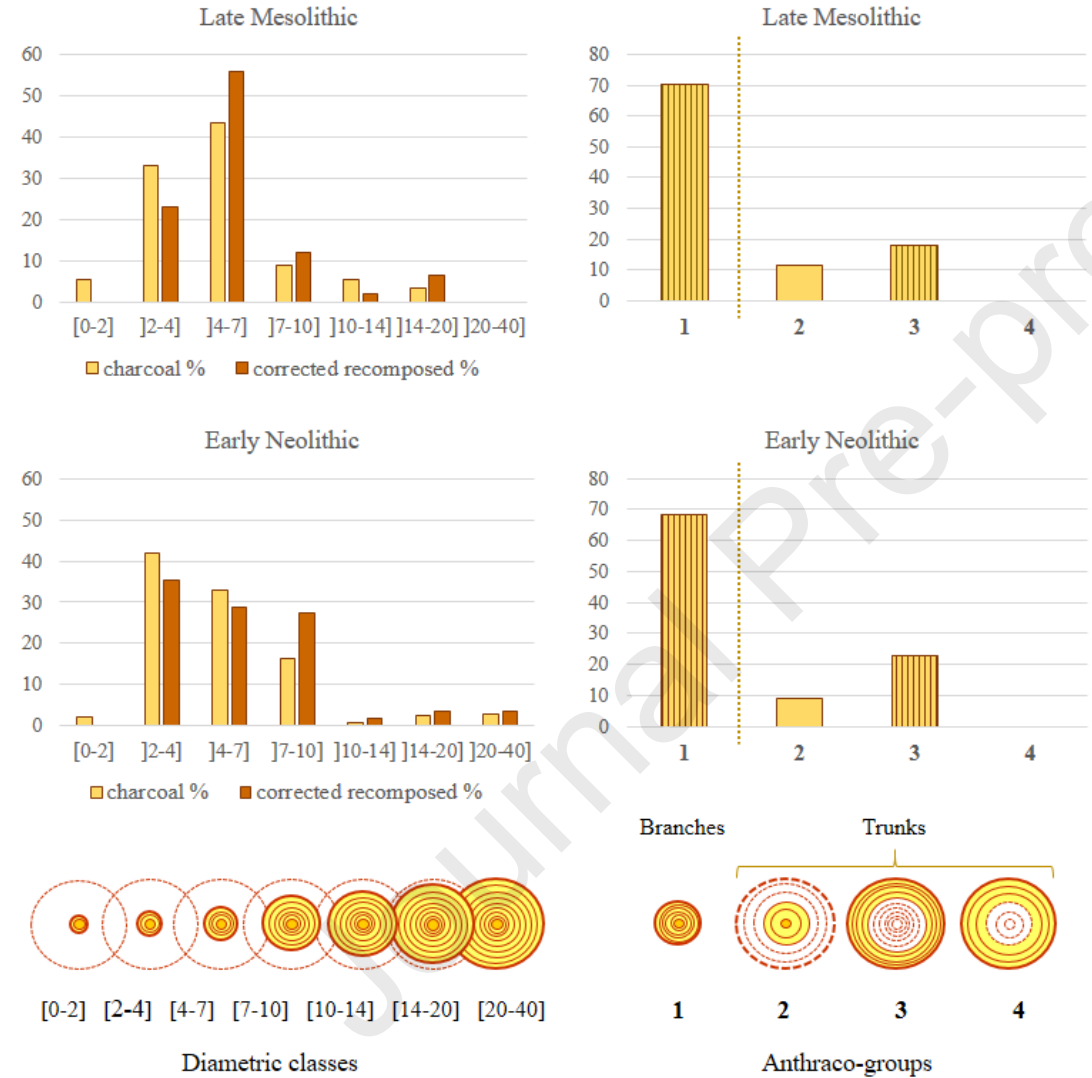

Diametric classes 


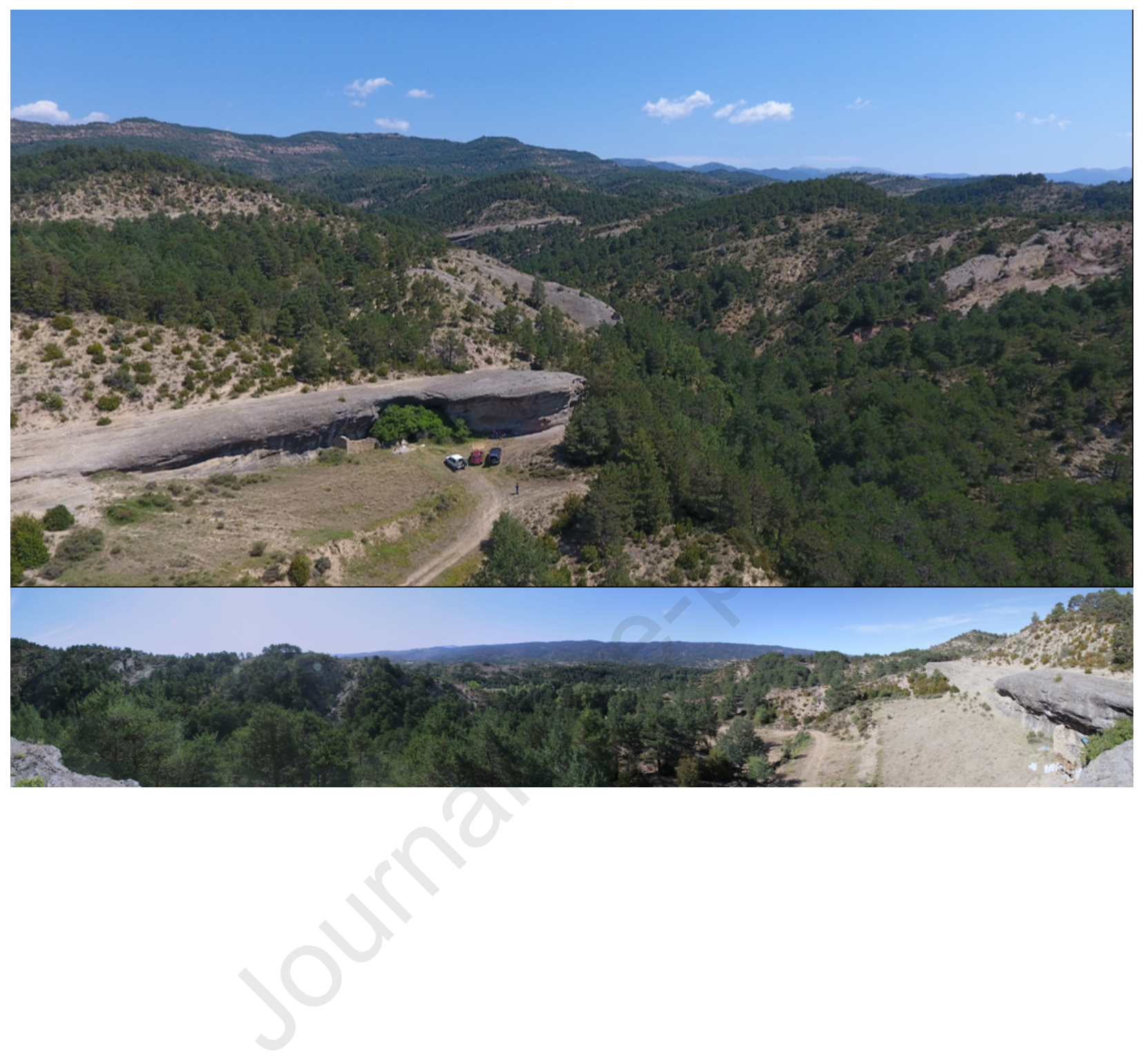




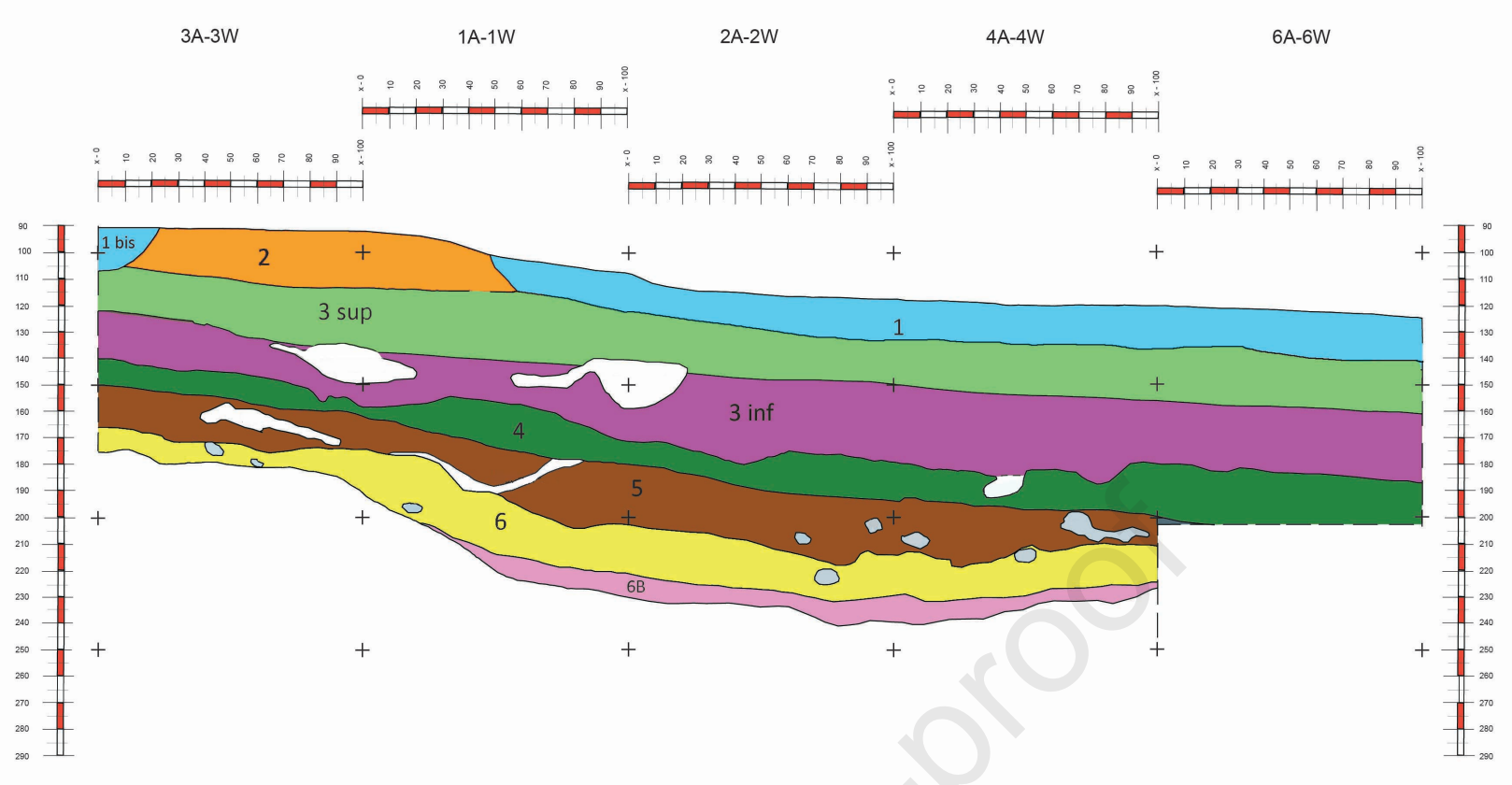




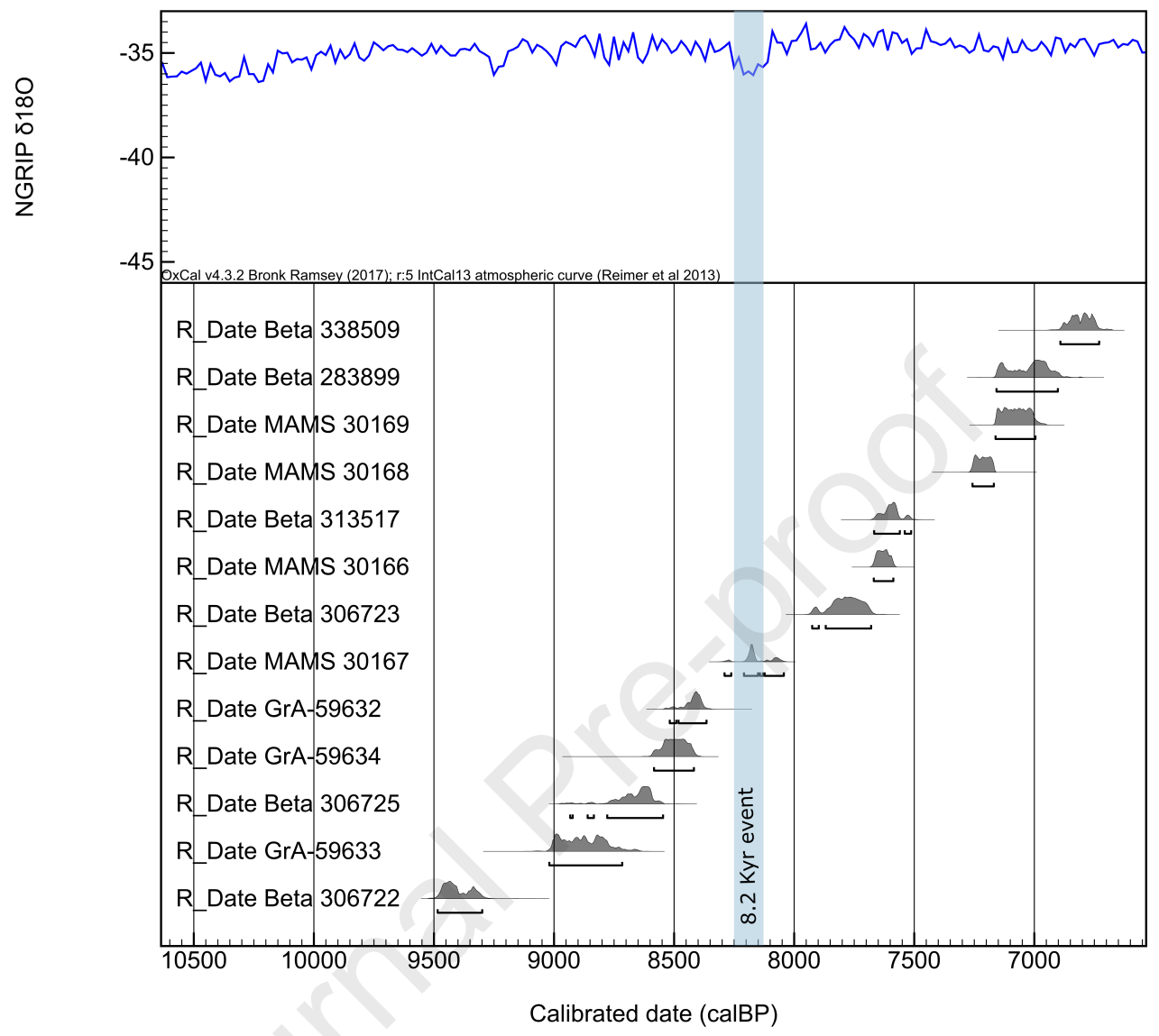




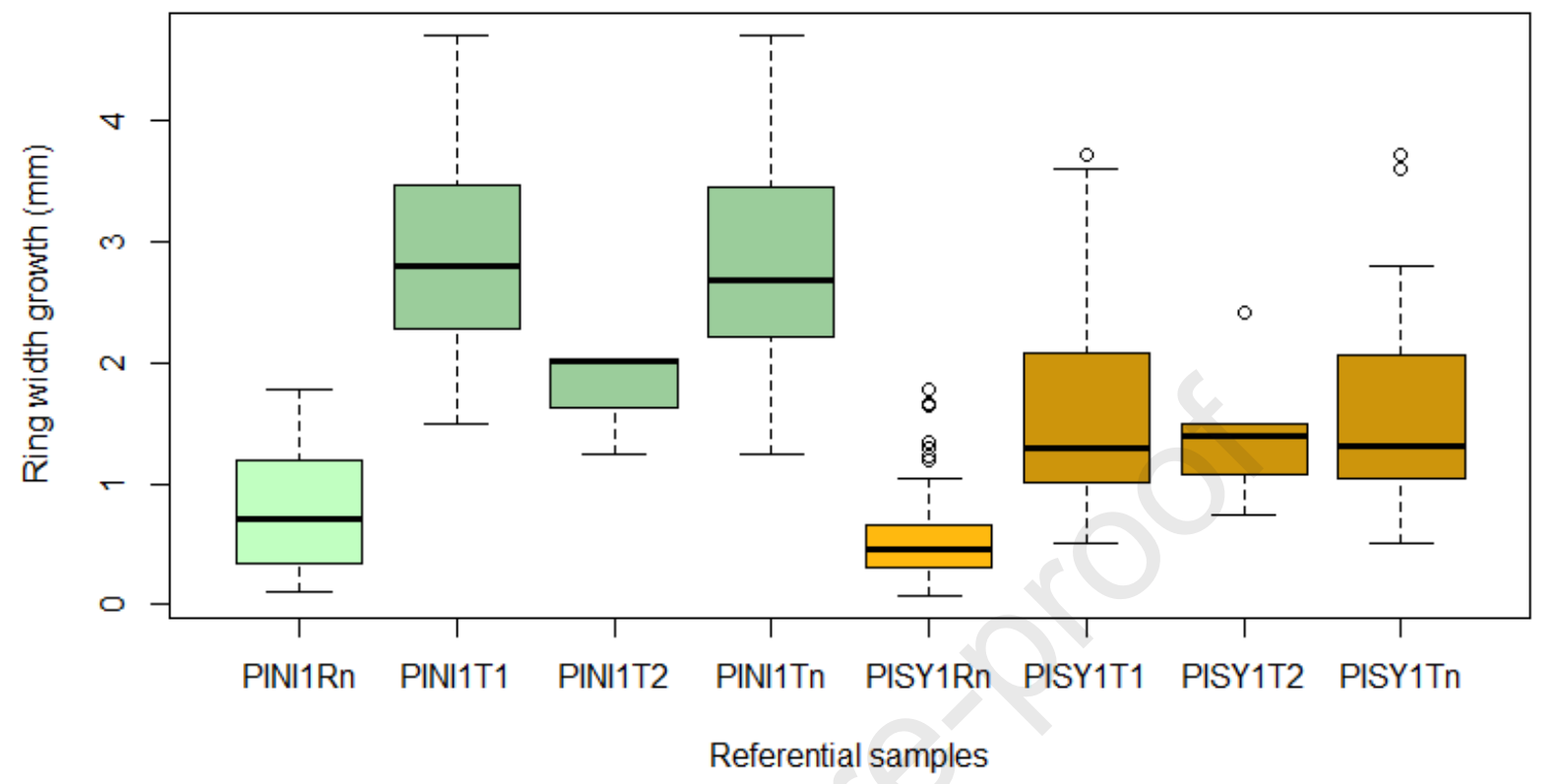




\begin{tabular}{|c|c|c|c|}
\hline $\begin{array}{l}\text { charcoal-pith } \\
\text { distance }\end{array}$ & tree-ring width & $\begin{array}{c}\text { anthraco- } \\
\text { groups }\end{array}$ & charcoal fragments \\
\hline \multirow[t]{2}{*}{ diameter $<7$} & $\begin{array}{l}\text { narrow rings } \\
<1 \mathrm{~mm} \\
\text { (slow growth) }\end{array}$ & 1 & $\begin{array}{c}1 \mathrm{~mm} \\
\square\end{array}$ \\
\hline & $\begin{array}{l}\text { large rings } \\
>1 \mathrm{~mm} \\
\square \\
\text { (fast growth) }\end{array}$ & 2 & \\
\hline \multirow[t]{2}{*}{ diameter $<7$} & $\begin{array}{c}\text { narrow rings } \\
<1 \mathrm{~mm} \\
\text { (slow growth) }\end{array}$ & 3 & \\
\hline & $\begin{array}{l}\text { large rings } \\
>1 \mathrm{~mm} \\
\square \\
\text { (fast growth) }\end{array}$ & 4 & $1 \mathrm{~mm}$ \\
\hline
\end{tabular}




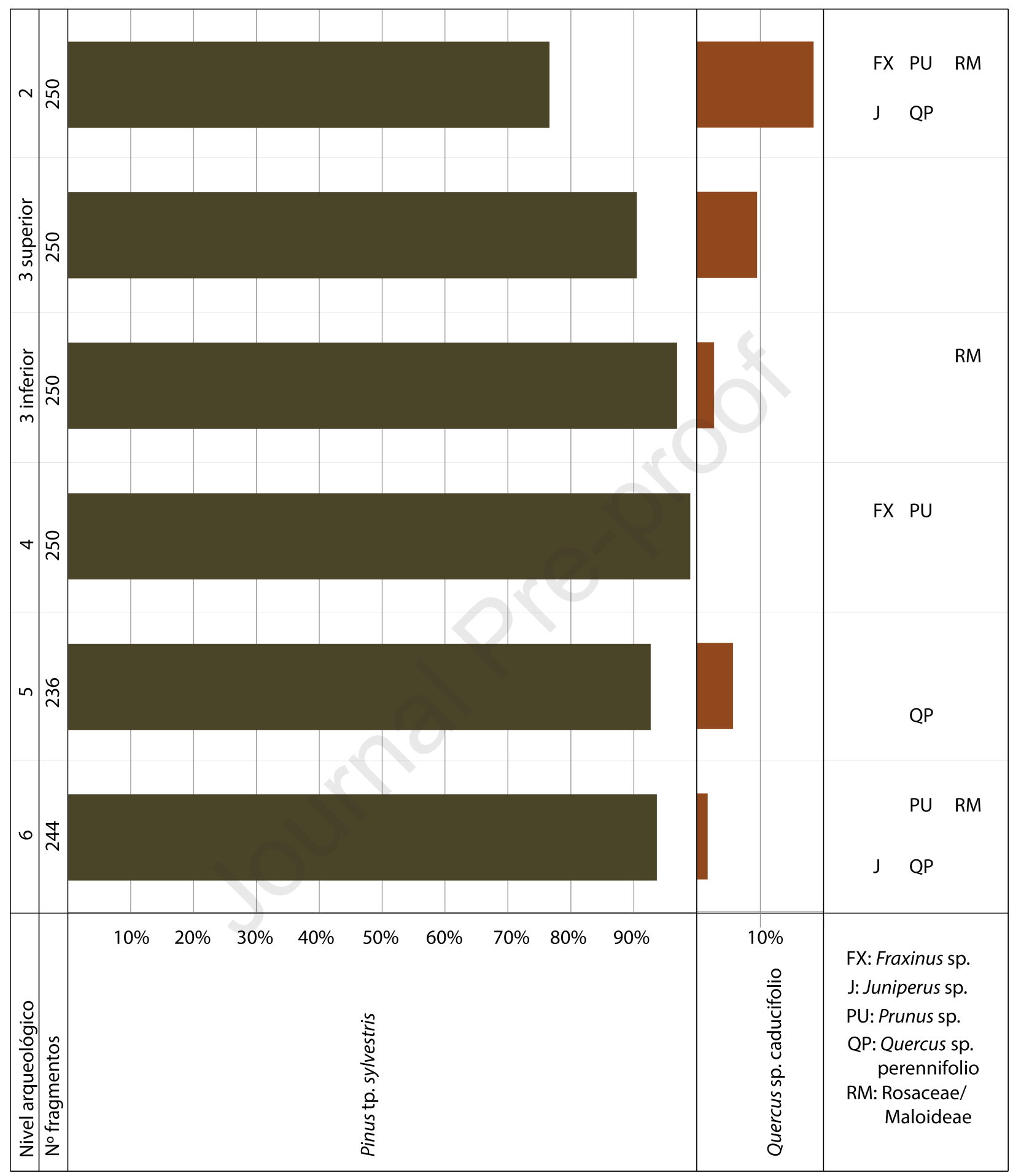




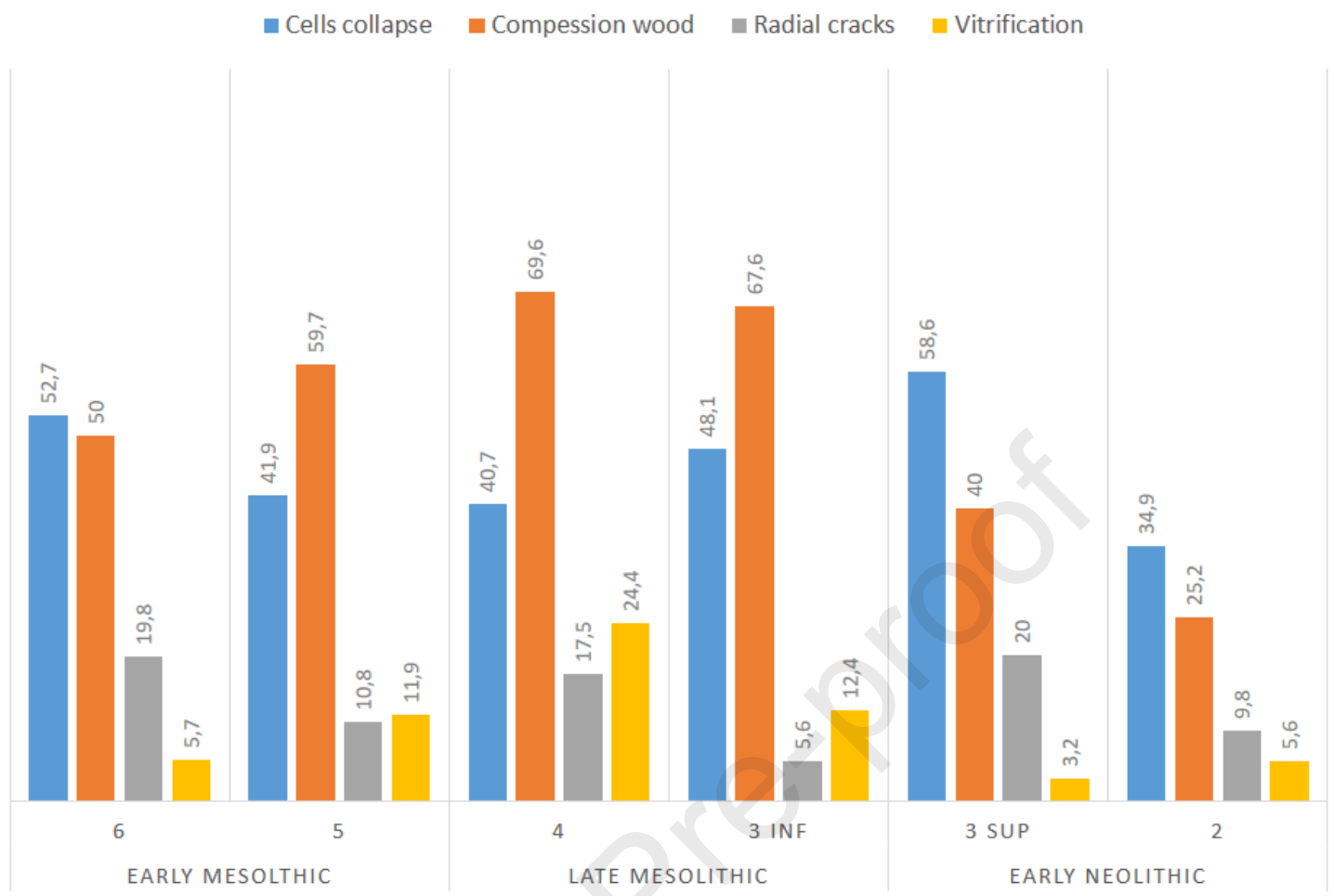




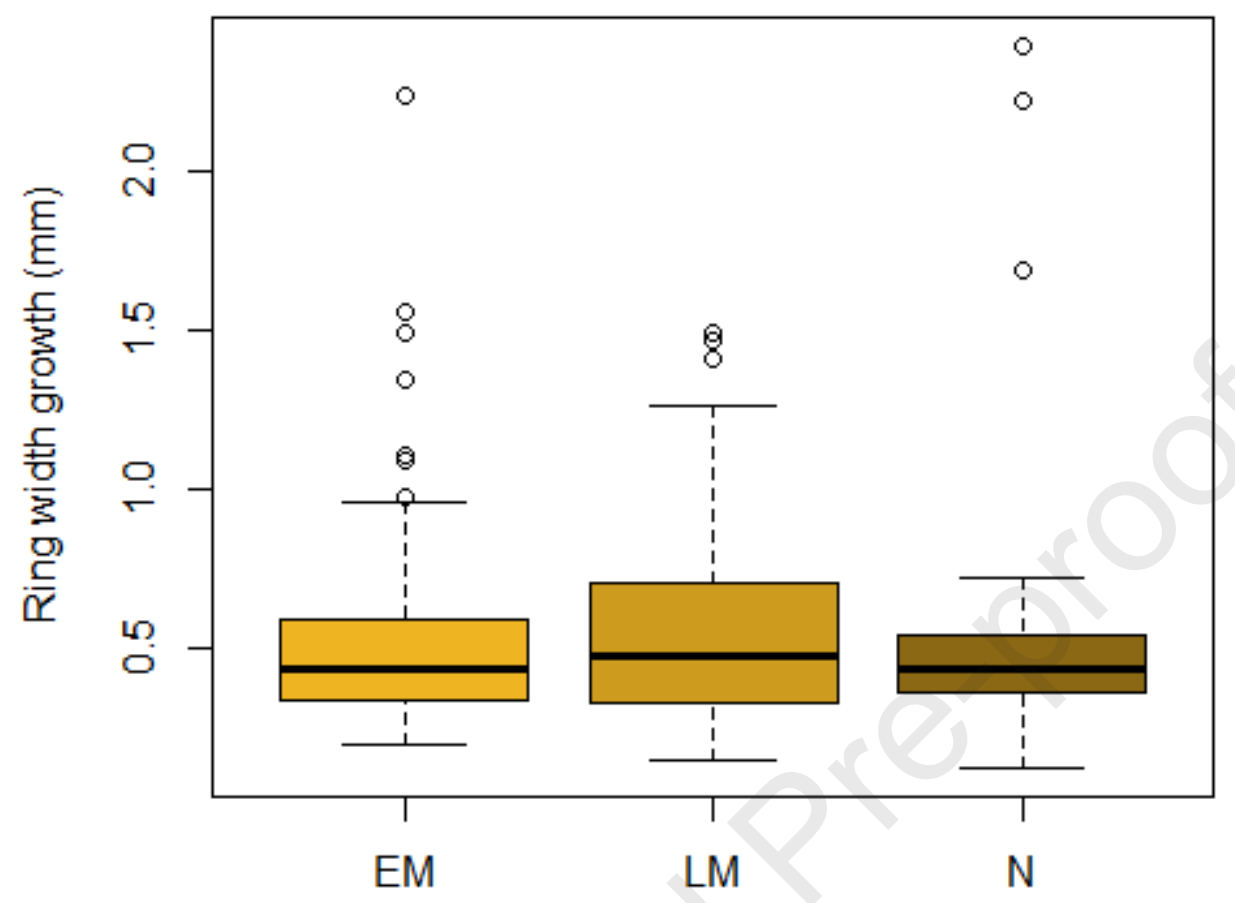

Chronocultural period 


\section{Declaration of interests}

$\bigotimes$ The authors declare that they have no known competing financial interests or personal relationships that could have appeared to influence the work reported in this paper.

$\square$ The authors declare the following financial interests/personal relationships which may be considered as potential competing interests: 